\title{
Continued disappearance of the benthic amphipod Diporeia spp. in Lake Michigan: is there evidence for food limitation?
}

\author{
Thomas F. Nalepa, David L. Fanslow, Andrew J. Foley, III, Gregory A. Lang, Brian \\ J. Eadie, and Michael A. Quigley
}

\begin{abstract}
Benthic surveys were conducted in the southern basin of Lake Michigan and throughout the lake to assess trends in benthic populations, emphasizing recent changes in densities of the benthic amphipod Diporeia spp. and dreissenid mussels. In the southern basin, Diporeia populations declined 89\%, 91\%, and 45\% between 1993 and 2002 at sites <30, 31-50, and 51-90 m, respectively. Lakewide, the population declined 65\% between 1994-1995 and 2000. Over the same time period, dreissenid densities, particularly Dreissena bugensis, increased. Intensive studies at $45 \mathrm{~m}$ sites in the southeastern region examined changes in lipid content, age structure, and benthic food inputs relative to the hypothesis that food limitation was a factor in Diporeia's disappearance. As Diporeia densities declined to zero, length-weight remained unchanged, and lipid content generally increased. Recruitment still occurred, but the young did not survive to become adults. Based on organic carbon, biogenic silica, and chlorophyll collected in sediment traps and found in the upper sediments, pelagic inputs to the benthic region still occurred. Our field observations and laboratory experiments did not disprove the hypothesis that food limitation from dreissenid filtering activities was the cause of the decline, but direct relationships between the loss of Diporeia and indicators of food availability were difficult to establish.
\end{abstract}

\begin{abstract}
Résumé : Nous avons inventorié le benthos dans le bassin sud du lac Michigan ainsi que dans le lac dans son ensemble afin de déterminer les tendances dans les populations benthiques, en particulier les changements récents de densité de l'amphipode benthique Diporeia spp. et des bivalves dreissénidés. Dans le bassin sud de 1993 à 2002 , les populations de Diporeia ont diminué respectivement de $89 \%, 91 \%$ et $45 \%$ dans les sites situés à <30, 31-50 et 5190 m, respectivement. À l'échelle du lac, les populations ont diminué de 65\% entre 1994-1995 et 2000. Durant la même période, les densités des dreissénidés, particulièrement de Dreissena bugensis, ont augmenté. Des études poussées aux sites de $45 \mathrm{~m}$ ont évalué les changements du contenu lipidique, de la structure d'âge et des apports de nourriture benthique en relation avec l'hypothèse voulant que la carence de nourriture soit un facteur dans la disparition de Diporeia. Au moment où les densités de Diporeia déclinaient vers zéro, la relation longueur-masse est restée inchangée et le contenu lipidique a en général augmenté. Il y avait encore du recrutement, mais les jeunes ne survivaient pas jusqu'à l'âge adulte. D'après les mesures de carbone organique, de silice biogénique et de chlorophylle effectuées dans les pièges à sédiments et dans les sédiments superficiels, il y avait encore des apports pélagiques vers la région benthique. Nos observations de terrain et nos expériences de laboratoire ne permettent pas de rejeter l'hypothèse d'une limitation alimentaire causée par les activités de filtration des dreissénidés comme cause du déclin, mais il est difficile d'établir des liens directs entre la perte des Diporeia et les indicateurs de disponibilité de nourriture.
\end{abstract}

[Traduit par la Rédaction]

\section{Introduction}

The increased spread of aquatic invasive species has led to the growing realization that these invaders, either individually or in concert, can change ecosystems at many levels of organization (Simon and Townsend 2003). A striking example is the Great Lakes ecosystem, where over the past 10-
15 years, species invasions have led to the loss of native species, altered pathways of energy and nutrient flux through food webs, and redefined fundamental understanding of ecosystem function (Nalepa et al. 1996; Vanderploeg et al. 2002; Hecky et al. 2004). When considering imposed changes within the Great Lakes, perhaps the most largescale, and certainly the most equivocal, has been the disap-

Received 26 January 2005. Accepted 1 December 2005. Published on the NRC Research Press Web site at http://cjfas.nrc.ca on 3 March 2006.

$\mathrm{J} 18519$

T.F. Nalepa, ${ }^{1}$ D.L. Fanslow, G.A. Lang, B.J. Eadie, and M.A. Quigley. Great Lakes Environmental Research Laboratory, National Oceanic and Atmospheric Administration (NOAA), 2205 Commonwealth Boulevard, Ann Arbor, MI 48105, USA. A.J. Foley, III. Institute for Limnology and Ecosystems Research, University of Michigan, 3038 A Dana Building, 440 Church Street, Ann Arbor, MI 48104, USA.

${ }^{1}$ Corresponding author (e-mail: thomas.nalepa@noaa.gov). 
pearance of the deepwater amphipod Diporeia spp. Declines in Diporeia populations have recently been documented in all the lakes except Lake Superior, and large areas in southeastern Lake Michigan (Nalepa et al. 1998), outer Saginaw Bay, Lake Huron (Nalepa et al. 2003), eastern Lake Erie (Dermott and Kerec 1997), and Lake Ontario (Dermott 2001; Lozano et al. 2001) are now mostly devoid of this organism.

Diporeia are part of a deepwater fauna that inhabit cold, proglaciated lakes, brackish estuaries, and coastal margins in the holarctic region (Bousfield 1989). Prior to its decline, Diporeia were the most abundant benthic macroinvertebrate in the deeper regions of all the Great Lakes, comprising $>70 \%$ of all benthic biomass at depths greater than $30 \mathrm{~m}$ (Cook and Johnson 1974; Nalepa 1989). Diporeia were also present but less dominant in nearshore regions $(<30 \mathrm{~m})$ of the open main basins and naturally absent from the shallow, warm bays and basins (i.e., inner Green Bay, inner Saginaw Bay, western and central Lake Erie). As an infaunal detritivore, Diporeia burrow in the upper $2 \mathrm{~cm}$ of sediment and feed mainly on organic material freshly settled from the water column (i.e., mostly diatoms). Feeding rates reach a seasonal maximum during and just after the spring diatom bloom, and populations can consume a large portion of energy inputs to the benthic region during this period (Dermott and Corning 1988; Fitzgerald and Gardner 1993). Diporeia, in turn, are fed upon by most fish species found in the offshore waters of the Great Lakes, including slimy and deepwater sculpin (Cottus cognatus and Myoxocephalus thompsonii, respectively), alewife (Alosa pseudoharengus), bloater (Coregonus hoyi), lake whitefish (Coregonus clupeaformis), yellow perch (Perca flavescens), and rainbow smelt (Osmerus mordax) (Anderson and Smith 1971; Scott and Crossman 1973; Wells 1980). As such, it serves as an important pathway by which energy fixed as primary production is cycled to upper trophic levels.

Declines of Diporeia populations in the Great Lakes were first noted in the early 1990s, and in all lake areas, these declines were coincident with the introduction and spread of the invading species Dreissena polymorpha (zebra mussel) and Dreissena bugensis (quagga mussel). A common hypothesis for the decline is that dreissenids are outcompeting Diporeia for available food (Nalepa et al. 1998; Dermott 2001). Dreissenids filter-feed near the sediment surface, and this hypothesis assumes that settling organic material is intercepted by dreissenids before it reaches the upper sediments and becomes available to Diporeia. Deepwater amphipods such as Diporeia (neararctic) and the closely related Monoporeia affinis (palearctic) are generally foodlimited, and both short- and long-term population trends have been attributed to changes in pelagic food inputs to the benthic region (Sarvala 1986; Johnson and Wiederholm 1992; Goedkoop and Johnson 2001). Yet despite the broad negative response of Diporeia to Dreissena, there are inconsistencies when examining decline patterns relative to the food-limitation hypothesis. For one, Diporeia populations have disappeared from several areas in the Great Lakes that were far-removed from dreissenid colonies and where potential food was still present in overlying waters and presumed to be settling to the bottom (Dermott 2001; Nalepa et al.
2003). Also, Diporeia are still abundant in some areas despite the presence of dreissenids (Dermott et al. 2005).

In this paper, we document recent spatial and temporal trends of Diporeia populations in Lake Michigan relative to expanding numbers of dreissenids. We also examine changes in age structure, physiological well-being, and pelagic food inputs during periods of population loss. These changes were compared with similar observations made prior to the introduction of dreissenids and Diporeia declines. Moreover, we conducted laboratory experiments to provide insights into our field observations and to further explore the foodlimitation hypothesis.

\section{Materials and methods}

\section{Spatial and temporal trends in densities}

To document long-term spatial and temporal trends in densities of Diporeia and Dreissena in Lake Michigan, benthic samples were collected over several time periods at sites located in the southern basin and also at sites located throughout the entire lake. In the southern basin, samples were collected at 40 sites in 1998-2002 (Fig. 1). Bottom substrates at the sites ranged from coarse sand and gravel to fine silt, and depths ranged from 16 to $157 \mathrm{~m}$. These 40 sites are part of a long-term monitoring program of the total macroinvertebrate community and have been sampled for 2 consecutive years every 5 years between 1980 and 1993 (Nalepa 1987; Nalepa et al. 1998). Consistent with this program, samples were again collected at these sites in 1998-1999. In 2000-2002, samples were collected at the same 40 sites and at 13 additional sites (A-4, C-2, C-45, F-2, F-3, G-45, K-2, N-2, N-3, T-3, M-45, R-45, SAU-45; Fig. 1). Whereas data from all 53 sites were used to better define spatial distributions of Diporeia and Dreissena in each of the 3 years, only data from the original 40 sites were used when examining temporal trends. Samples in 1998-1999 were collected in spring (mid-May to early June), summer (late July to early August), and fall (September to October), but in 2000-2002, samples were collected only in fall. For analysis purposes, sites were divided into four depth intervals: 16-30, 31-50, 51-90, and $>90 \mathrm{~m}$. These depth intervals are consistent with prior characterization of depth-macroinvertebrate associations in Lake Michigan (Nalepa 1987).

Densities of Diporeia and Dreissena were determined throughout Lake Michigan by sampling at 158 sites in late summer-fall 2000. Besides the 53 sites sampled in the southern basin, an additional 105 sites were sampled in the central and northern basins, Green Bay, and Grand Traverse Bay. Many of these sites (42 of 105) were sampled previously in 1994-1995 (Nalepa et al. 2000).

Methods of collection and analysis were the same for all sampling periods. Sediment samples were taken in triplicate with a Ponar grab $\left(\right.$ area $\left.=0.046 \mathrm{~m}^{2}\right)$ at each site and washed into an elutriation device fitted with a nitex sleeve with $0.5 \mathrm{~mm}$ openings. Retained material was immediately preserved in 5\% buffered formalin containing Rose Bengal stain. In the laboratory, all macrobenthic organisms in the 19981999 samples were picked, counted, and sorted into major taxonomic groups (Amphipoda, Oligochaeta, Chironomidae, Dreissena, Sphaeriidae) under a low-power magnifier lamp 
Fig. 1. Sampling sites in southern Lake Michigan, USA (inset shows location in the Great Lakes area). Depth contours are 25, 50, and $100 \mathrm{~m}$.

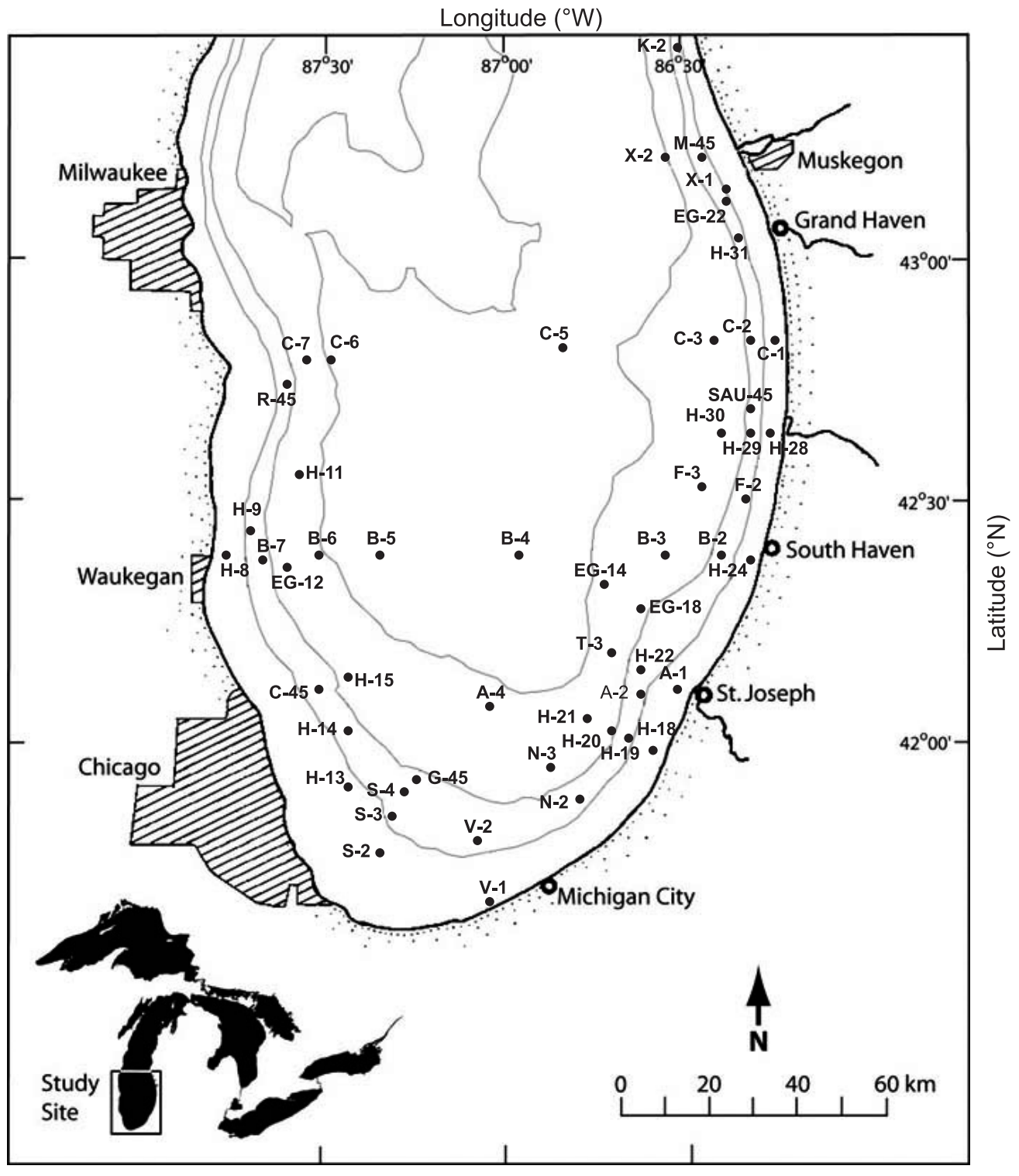

(1.5x). Chironomidae densities were low as in previous years and therefore not reported here. Only Diporeia and Dreissena were enumerated in samples collected in 2000-2002.

For the southern basin, differences in densities of Diporeia and Dreissena over the 1992-2002 period, as well as differences in densities of Oligochaeta and Sphaeriidae over the 1992-1999 period, were tested using a two-way analysis of variance (ANOVA; year $\times$ depth interval) on individual replicates. For the lakewide surveys in 1994-1995 and 2000, density differences of Diporeia and Dreissena were tested using a two-way ANOVA as above (period $\times$ depth interval). Additionally, the lake was divided into south, central, and north regions (Nalepa et al. 2000), and a two-way ANOVA (year $\times$ region) was used to test differences separately within each depth interval. For all ANOVAs in the southern basin and lakewide surveys, the data were log-transformed $(\ln +1)$ to homogenize variances and post hoc multiple-range tests (Tukey's honestly significant difference (HSD)) were performed using Bonferroni-adjusted $p$ values.
Population age structure, physiological condition, and physical variables

Soon after it became apparent that the Diporeia population in the southern basin was declining (Nalepa et al. 1998), we initiated a monthly sampling program in 1997 at four sites in the southeastern portion of the lake to document trends in age structure, lipid content, and length-weight and also to document relative amounts of potential food settling to the benthic region. The sites were located at $45 \mathrm{~m}$ water depth off St. Joseph (H-22; 42 $\left.{ }^{\circ} 08.35 \mathrm{~N}, 86^{\circ} 39.83 \mathrm{~W}\right)$, Saugatuck (SAU-45; 42 $\left.41.14 \mathrm{~N}, 86^{\circ} 18.90 \mathrm{~W}\right)$, Grand Haven (H-31; 43 $\left.02.47 \mathrm{~N}, 86^{\circ} 19.99 \mathrm{~W}\right)$, and Muskegon (M-45; $43^{\circ} 11.27 \mathrm{~N}, 86^{\circ} 25.78 \mathrm{~W}$ ) (Fig. 1). Based on sampling prior to 1997, we knew that the state of populations at these four sites varied widely. The population had already disappeared at $\mathrm{H}-22$, was present but declining at SAU-45 and H-31, and was still abundant at M-45. Both $\mathrm{H}-22$ and $\mathrm{H}-31$ were part of our long-term monitoring program, and SAU-45 was located near a long-term monitoring site of similar depth (B-2). 
Samples for density estimates of Diporeia and Dreissena at $\mathrm{H}-31$ had also been collected one to four times per year in 1994, 1995, and 1996. In 1997 and 1998, Ponar samples at all four sites were collected monthly from late March-April to late October-November. After 1998, monthly sampling continued at sites where Diporeia were still present and lasted until it was no longer found.

Beginning in 1994 at H-31 and in 1997 at the other $45 \mathrm{~m}$ sites, body lengths of Diporeia in each of the replicate samples were determined by first tracing individuals (body midline) under $12 \times$ magnification using a camera lucida and then measuring tracings with a digitizer (Quigley and Lang 1989). Measurements were made from the base of the rostrum to the tip of the telson. In replicates with high numbers of individuals, animals were subsampled using a Folsom plankton splitter, and lengths were determined on at least 75-100 animals. In addition, body lengths were determined on animals in Ponar grabs collected monthly (April to November) at H-31 in 1986-1988. For these samples, all individuals in one replicate grab were measured. After lengths were determined, animals were placed into three size categories: $0-3,3-5$, and $>5 \mathrm{~mm}$. At depths of about $45 \mathrm{~m}$ in the Great Lakes, these sizes represent newly recruited young (YOY), juveniles, and adults, respectively (Winnell and White 1984; Johnson 1988).

On each sampling date beginning in 1994, extra Ponar grabs were taken at each site for the determination of Diporeia lipid content and length-weight. Upon collection, entire grab samples (animals, sediments, and overlying waters) were placed into plastic bags and kept cool during transport back to the laboratory. Within $24 \mathrm{~h}$ of collection, 20-25 juveniles and adults were placed individually into preweighed minitest tubes $(6 \mathrm{~mm} \times 50 \mathrm{~mm})$. For YOY, 5-10 individuals were placed into each tube (3-5 replicates). Before animals were placed into the tubes, individual body lengths were traced and later measured. The animals were dried for $48 \mathrm{~h}$ (under $\mathrm{N}_{2}$ at $50-60{ }^{\circ} \mathrm{C}$ ) and then stored frozen under vacuum until lipid extraction. Animals were reweighed just prior to lipid extraction, and individual animal weights were used to derive length - dry weight relationships. For YOY, mean length and weight were used in derived relationships. Total lipids were extracted using chloroform-methanol (2:1), quantified gravimetrically, and reported as percent dry weight (Gardner et al. 1985a). Differences in lipid content between years and age classes were examined with a two-way ANOVA after arcsine transformation.

Sediment traps were deployed at the $45 \mathrm{~m}$ sites to measure potential pelagic inputs to the benthic region. In 1997, settling material was collected with a sequencing sediment trap that consisted of a cylinder with a $20 \mathrm{~cm}$ opening and 8:1 aspect ratio (Muzzi and Eadie 2002). A bottom funnel led to an attached array of twenty-three $60 \mathrm{~mL}$ bottles within a rotating carousel. The carousal was programmed to rotate so a new bottle collected every 9 days. Before deployment, each bottle was filled with $30 \mathrm{mg}$ mercuric chloride to prevent microbial activity. The traps were deployed just below the thermocline (30 m water depth) from March - early April to October 1997 at SAU-45, H-31, and M-45. In 1998 and 1999, sediment traps consisted of a cylinder with an opening of $10 \mathrm{~cm}$ and an aspect ratio of $5: 1$. The cylinder had a funnel at the bottom connected to a $500 \mathrm{~mL}$ bottle that had $20 \mathrm{~mL}$ chloroform as a preservative. Intercalibrations showed these traps collected at the same rate as the sequencing traps deployed in 1997 (Muzzi and Eadie 2002). Traps were deployed at all four $45 \mathrm{~m}$ sites in 1998 and at H-31 and M-45 in 1999. Traps were retrieved and bottles replaced on a monthly basis between March - early April and October.

After retrieval, collected material was poured through a $500 \mu \mathrm{m}$ screen to remove benthos and large zooplankton and then allowed to settle for at least $24 \mathrm{~h}$ before the supernatant was decanted. The samples were then freeze-dried and kept frozen until analysis. Total organic carbon (TOC) was analyzed with a Carlos Erba CHN elemental analyzer. Prior to analysis, subsamples for TOC were treated with $2 \mathrm{~mol} \cdot \mathrm{L}^{-1}$ HCL, shaken for $24 \mathrm{~h}$, and then dried at $60{ }^{\circ} \mathrm{C}$ to remove mineral carbonates. Chlorophyll $a(\mathrm{Chl})$ was determined according to the method of Hansson (1988). Biogenic silica (BiS) was determined by first using a wet alkaline method for digestion and then measuring concentrations of $\mathrm{SiO}_{2}$ with an Alpkem FS3000 analyzer (Krausse et al. 1983).

During each monthly sampling in 1998, an extra Ponar grab was collected at all four sites for determination of sediment TOC, BiS, and Chl. Monthly samples were also collected at H-31 in 1999 and at M-45 in 1999-2002. The top 0-1 cm of sediment was scraped from the surface of grab samples, freeze-dried, and analyzed as given above. Based on dated sediment cores collected in 2001, sediment accumulation rates at $\mathrm{H}-22$ are about $1 \mathrm{~cm} \cdot$ year $^{-1}$ (J. Robbins, Great Lakes Environmental Research Laboratory, 2205 Commonwealth Boulevard, Ann Arbor, MI 48105, USA, unpublished data); thus, the $0-1 \mathrm{~cm}$ layer provided a good characterization of material deposited on an annual basis. Rates were likely less at the other $45 \mathrm{~m}$ sites, and this layer would therefore represent at least several years of accumulation. Grain size of sediment samples collected in 1998 was measured with a laser particle counter. Differences between years for individual constituents were tested with a one-way ANOVA, with sampling dates as within-year replicates.

Material collected in sediment traps consisted of material resuspended from the bottom by storm events and also of autochthonous material settled from the water column. To better define the latter source, a correction was made to calculated flux rates. Concentrations of TOC, BiS, and Chl measured for local surface sediment was subtracted from the concentration in the trapped material. This value was then multiplied by mass flux to produce an estimate of TOC, BiS, and $\mathrm{Chl}$ delivered to the site from sources other than local resuspension. Since not all sediment constituents were measured in 1997, corrections in that year were made based on 1998 values.

\section{Laboratory experiments}

Several laboratory experiments were conducted to provide insights into potential causes for the population decline. All experiments were conducted in a dark environmental chamber set at $4{ }^{\circ} \mathrm{C}$. Purposes of the first experiment were to determine if sediments from a site where the population had recently disappeared were acutely toxic to Diporeia and to determine if these sediments had any nutritional value. Sediments were collected with a Ponar grab at two of the $45 \mathrm{~m}$ sites (H-31 and M-45) on 10 May 2000. At the time, mean densities of Diporeia were $0 \cdot \mathrm{m}^{-2}$ and $6500 \cdot \mathrm{m}^{-2}$ at the two 
sites, respectively. The top $1 \mathrm{~cm}$ of sediment from each site was scraped from grab samples, placed into prerinsed glass jars $(500 \mathrm{~mL})$, and kept cool. Experimental animals at M-45 were collected by placing entire grab samples into plastic bags and kept at $4{ }^{\circ} \mathrm{C}$ until the experiments were initiated.

Within $24 \mathrm{~h}$ of collection, sediments from each site were washed through a $0.5 \mathrm{~mm}$ screen to remove macroinvertebrates, allowed to settle, and then placed into glass scintillation vials $(20 \mathrm{~mL})$. Enough sediment was placed in the vials to achieve a depth of $2 \mathrm{~cm}$, which is similar to Diporeia's normal burrowing depth. Vials were filled with filtered lake water $(0.45 \mu \mathrm{m}$ Millipore filter $)$ that had been collected from near bottom at M-45. There were four treatments: filtered lake water only, medium sand, H-31 sediment, and M-45 sediment. The sand was prerinsed and ashed at $550{ }^{\circ} \mathrm{C}$ for $1 \mathrm{~h}$. All vials were placed into an aquarium filled with filtered, aerated lake water and allowed to stabilize for $24 \mathrm{~h}$. After the stabilization period, one animal $(>5 \mathrm{~mm})$ was placed into each vial, and the vial was then covered with nitex screen (mesh opening $0.5 \mathrm{~mm}$ ) to prevent animals from escaping and yet allowing water exchange to take place. As animals were placed into the treatment vials, 28 animals were randomly selected and frozen for later analysis of lipid content. On 21 May (10 days), 30 May (19 days), 21 June (41 days), and 16 July (66 days), at least 10 vials from each of the four treatments were removed and the animal's condition (live or dead) recorded. Lipid content of 5-10 living animals was measured as given above. Based on the volume of sediment in the vials $\left(11.45 \mathrm{~cm}^{2}\right)$ and typical ingestion rates (Dermott and Corning 1988), experimental animals would have ingested only a small fraction $(<1 \%)$ of the provided sediment during the 66-day experiment. The results were analyzed using a two-way ANOVA (treatment $\times$ day) after arcsine transformation. In the analysis, initial lipid content (day 0) for each treatment was derived by randomly assigning lipid content of the 28 pre-experimental animals to the treatments ( $n=7$ per treatment).

The second experiment consisted of preference-avoidance trials with sediments from $\mathrm{H}-31$ and M-45. The purpose of this experiment was to determine if Diporeia actively avoided sediments from $\mathrm{H}-31$, a site where populations had recently disappeared. On 14 July 2000 , sediments $(0-1 \mathrm{~cm})$ from both sites were collected with a Ponar grab, placed into plastic bags, and kept cool. Within $24 \mathrm{~h}$ of collection, sediments were screened and placed into labeled Petri dishes $(47 \mathrm{~mm}$ diameter $\times 1.5 \mathrm{~cm}$ depth), with six dishes per site. Three dishes from each site along with three dishes with ashed sand (control) were randomly placed into each compartment of a two-compartment aquarium containing filtered lake water. Thus, there were duplicate trials, with each trial having three replicates per treatment. After a $24 \mathrm{~h}$ stabilization period, 100 Diporeia (collected at M-45) were placed into each compartment. Dishes were carefully removed after $120 \mathrm{~h}$, sediments washed through a $500 \mu \mathrm{m}$ mesh screen, and the number of animals burrowed into each dish recorded. Differences among the three treatments were determined using a one-way ANOVA followed by Tukey's HSD. There were no significant differences between the two trials for each treatment ( $t$ test, $\mathrm{df}=5, P>0.05$ ), so trial replicates were not distinguished in the ANOVA ( $n=6$ for each treatment).

\section{Results}

\section{Density trends of major taxa groups in the southern basin, 1992-2002}

Declines in Diporeia populations in the southern basin, which were initially documented in 1992-1993 (Nalepa et al. 1998), continued through 2002 (Table 1). Over the 19922002 period, significant differences in Diporeia densities occurred for years $\left(F_{[6,1751]}=96.84, P=0.0001\right)$, intervals $\left(F_{[3,1751]}=249.50, P=0.0001\right)$, and year $\times$ interval interaction $\left(F_{[18,1751]}=11.95, P=0.0001\right)$. Annual densities in 1998-2002 were not significantly different from each other but were significantly lower than densities found in 1992 and $1993(P<0.05$, Tukey's HSD). Mean densities at the $<30,31-50$, and $51-90 \mathrm{~m}$ intervals decreased by $89.4 \%$, $90.5 \%$, and 44.6\%, respectively, between 1992 and 2002. Declines were more pronounced on the east side of the basin than on the west side as lower densities, first observed in the southeastern portion of the basin in 1992, extended farther north and offshore over time (Fig. 2). By 2002, Diporeia were rare or completely gone to depths of at least $50 \mathrm{~m}$ in an area from near Chicago to Grand Haven. Of 23 sites sampled in 2002 that were in less than $50 \mathrm{~m}$ water depth, Diporeia were present only at Stations H-8, B-7, and EG-12, all on the west side of the basin (densities $3155 \cdot \mathrm{m}^{-2}, 4091 \cdot \mathrm{m}^{-2}$, and $3150 \cdot \mathrm{m}^{-2}$, respectively). Although still present, densities at these three sites in 2002 were lower than densities found in 1993 (declines of 46.2\%, 46.2\%, and 68.4\%, respectively).

Whereas Diporeia continued to decline between 1992 and 2002 , the dreissenid population became more widespread and abundant (Table 1). Differences in densities of Dreissena were significant for years $\left(F_{[6,1751]}=13.43, P=\right.$ $0.0001)$, intervals $\left(F_{[3,1751]}=218.70, \stackrel{P}{P}=0.0001\right)$, and year $\times$ interval interaction $\left(F_{[18,1751]}=6.08, P=0.0001\right)$. Over the 10-year period, dreissenids were mostly confined to depths $<50 \mathrm{~m}$, and greatest increases occurred at the 31$50 \mathrm{~m}$ interval. At this interval, mean densities of $D$. polymorpha increased from $7 \cdot \mathrm{m}^{-2}$ in 1992 to $1112 \cdot \mathrm{m}^{-2}$ in 2002. The other dreissenid species, D. bugensis, was first collected in the southern basin in 2001. By 2002, mean density at the $31-50 \mathrm{~m}$ interval had increased to $752 \cdot \mathrm{m}^{-2}$ (Table 1). Mean density of the dreissenid population at the three west-side sites where Diporeia were still present in 2002 (H-8, B-7, and EG-12; total of nine replicates) were not significantly different from densities at the other 20 sites (total of 60 replicates) of similar depth $(<50 \mathrm{~m})$, where Diporeia had disappeared $(t$ test, $\mathrm{df}=67, P=0.98$, $\ln +1$ transformed).

Abundances of oligochaetes and sphaeriids in the southern basin were documented only in 1992-1993 and 1998-1999 (Table 1). Differences in oligochaete densities were significant for years $\left(F_{[3,1403]}=2.99, P=0.03\right)$, intervals $\left(F_{[3,1403]}=84.88, P=0.0001\right)$, and year $\times$ interval interaction $\left(F_{[9,1403]}=5.34, P=0.0001\right)$. Densities in 1993 were significantly lower than the other 3 years $(P=0.03$, Tukey's HSD), but a consistent temporal trend over the entire 19921999 period was not apparent at any of the four intervals (Table 1). Sphaeriid densities were also significantly different for years $\left(F_{[3,1403]}=12.29, P=0.0001\right)$, intervals $\left(F_{[3,1403]}=156.25, P=0.0001\right)$, and year $\times$ interval interaction $\left(F_{[9,1403]}=9.48, P=0.0001\right)$. The general trend was 
Table 1. Mean ( \pm standard error) densities $\left(\right.$ no. $\cdot \mathrm{m}^{-2}$ ) of the major taxa found in southern Lake Michigan in 1992-2002.

\begin{tabular}{|c|c|c|c|c|c|c|c|}
\hline \multirow[b]{2}{*}{ Taxa } & \multicolumn{7}{|l|}{ Year } \\
\hline & 1992 & 1993 & 1998 & 1999 & 2000 & 2001 & 2002 \\
\hline \multicolumn{8}{|l|}{$16-30 \mathrm{~m}(n=11)$} \\
\hline Oligochaeta & $1713 \pm 376$ & $1647 \pm 434$ & $2367 \pm 600$ & $2085 \pm 624$ & - & - & - \\
\hline Sphaeriidae & $1381 \pm 384$ & $535 \pm 123$ & $340 \pm 247$ & $309 \pm 142$ & - & - & - \\
\hline Dreissena polymorpha & $389 \pm 253$ & $1929 \pm 1698$ & $978 \pm 255$ & $2056 \pm 1014$ & $617 \pm 340$ & $193 \pm 74$ & $885 \pm 464$ \\
\hline \multicolumn{8}{|l|}{$31-50 \mathrm{~m}(n=12)$} \\
\hline Diporeia & $8710 \pm 759$ & $7021 \pm 870$ & $1957 \pm 883$ & $892 \pm 450$ & $1427 \pm 847$ & $1364 \pm 798$ & $665 \pm 395$ \\
\hline Oligochaeta & $4487 \pm 466$ & $3166 \pm 330$ & $4518 \pm 1146$ & $6029 \pm 2219$ & - & - & - \\
\hline Sphaeriidae & $2273 \pm 303$ & $1068 \pm 166$ & $1434 \pm 294$ & $707 \pm 162$ & - & - & - \\
\hline Dreissena polymorpha & $7 \pm 3$ & $25 \pm 12$ & $433 \pm 156$ & $1059 \pm 414$ & $865 \pm 555$ & $1298 \pm 858$ & $1112 \pm 755$ \\
\hline Dreissena bugensis & $0 \pm 0$ & $0 \pm 0$ & $0 \pm 0$ & $0 \pm 0$ & $0 \pm 0$ & $5 \pm 5$ & $752 \pm 495$ \\
\hline \multicolumn{8}{|l|}{$51-90 \mathrm{~m}(n=11)$} \\
\hline Sphaeriidae & $801 \pm 153$ & $384 \pm 72$ & $660 \pm 100$ & $578 \pm 94$ & - & - & - \\
\hline Dreissena polymorpha & $1 \pm 1$ & $1 \pm 1$ & $5 \pm 3$ & $3 \pm 2$ & $8 \pm 5$ & $13 \pm 7$ & $20 \pm 15$ \\
\hline Dreissena bugensis & $0 \pm 0$ & $0 \pm 0$ & $0 \pm 0$ & $0 \pm 0$ & $0 \pm 0$ & $0 \pm 0$ & $8 \pm 5$ \\
\hline \multicolumn{8}{|l|}{$>90 \mathrm{~m}(n=6)$} \\
\hline Diporeia & $3195 \pm 389$ & $3226 \pm 515$ & $4833 \pm 762$ & $1794 \pm 249$ & $2814 \pm 570$ & $2608 \pm 392$ & $3623 \pm 647$ \\
\hline Oligochaeta & $1179 \pm 151$ & $1123 \pm 159$ & $1009 \pm 176$ & $1034 \pm 222$ & - & - & - \\
\hline Sphaeriidae & $113 \pm 30$ & $98 \pm 36$ & $197 \pm 99$ & $154 \pm 84$ & - & - & - \\
\hline Dreissena polymorpha & $0 \pm 0$ & $0 \pm 0$ & $4 \pm 4$ & $0 \pm 0$ & $0 \pm 0$ & $0 \pm 0$ & $0 \pm 0$ \\
\hline Dreissena bugensis & $0 \pm 0$ & $0 \pm 0$ & $0 \pm 0$ & $0 \pm 0$ & $0 \pm 0$ & $0 \pm 0$ & $0 \pm 0$ \\
\hline
\end{tabular}

Note: Oligochaeta and Sphaeriidae were not sampled in 2000-2002. The number of sites $(n)$ in each of the four depth intervals are shown in parentheses.

for a decline in densities at the two shallowest depth intervals over the period.

\section{Lakewide density trends, 1994-1995 to 2000}

Comparisons of lakewide densities in 1994-1995 and 2000 indicated that declines of Diporeia occurred not only in the southern basin but also throughout the lake (Fig. 3). Mean lakewide density was 65\% lower in 2000 compared with 1994-1995, and this difference was significant $\left(F_{[1,234]}=53.38, P=0.0001\right)$. The decline occurred across all depth intervals, as the year $\times$ interval interaction was not significant $\left(F_{[3,234]}=2.16, P=0.09\right)$. Densities at the $<30,31-50,51-90$, and $>90 \mathrm{~m}$ intervals were $77.9 \%$, $73.7 \%, 53.2 \%$, and $51.6 \%$ lower, respectively (Table 2). Further, the extent of the decline was greatest in the northern region; the overall decline was $91.4 \%$ in the north compared with $65.0 \%$ and $42.4 \%$ in the south and central regions, respectively. While densities were lower in the north in each of the four depth intervals, a regional difference was only significant at the $>90 \mathrm{~m}$ interval $\left(F_{[2,34]}=\right.$ 8.58, $P=0.001$; Tukey's HSD, $P<0.003)$. Lakewide densities of Dreissena were significantly higher in 2000 compared with 1994-1995 $\left(F_{[1,236]}=38.04, P=0.0001\right)$. At sites $<50 \mathrm{~m}$, mean dreissenid densities were highest in the northern region in both sampling periods, which may explain greater declines of Diporeia in this portion of the lake.

\section{Annual density trends, $45 \mathrm{~m}$ sites}

From the long-term monitoring program, densities of Diporeia were available for three of the $45 \mathrm{~m}$ sites $(\mathrm{H}-22$, SAU-45, and H-31) in 1980-1981 and 1986-1987, which were the years just prior to the first report of Dreissena in Lake Michigan (first reported in 1989; Marsden et al. (1993)). Mean annual density of Diporeia by site and year ranged from 5347 to $14044 \cdot \mathrm{m}^{-2}$ (Fig. 4). Beginning in 1992, the population declined systematically, first at the southern-most site (H-22) and later at the more northern sites. By fall 2002, Diporeia had disappeared from all four sites (Figs. 4, 5). Whereas Diporeia disappeared from each site within a 10year period, rates and patterns of decline were site-specific. In 1992 , densities at $\mathrm{H}-22$ declined from $10600 \cdot \mathrm{m}^{-2}$ in spring to $200 \cdot \mathrm{m}^{-2}$ in fall, a $98 \%$ decline in just 6 months. Declines to total loss were more gradual at the other $45 \mathrm{~m}$ sites, occurring between 1994 and 1999 at H-31 and between 1997 and 2002 at M-45. Unlike populations at the other $45 \mathrm{~m}$ sites, the population at M-45 recovered somewhat after initial declines were observed. Densities increased throughout 1999 and remained higher into spring 2000; however, densities decreased thereafter (Fig. 5). When considering all four $45 \mathrm{~m}$ sites, the period of time in which Diporeia declined from densities of $5300-14000 \cdot \mathrm{m}^{-2}$ to $<200 \cdot \mathrm{m}^{-2}$ varied from 0.5 to 5 years.

The relationship between annual densities of Diporeia and Dreissena was examined over the time period between just 
Fig. 2. Mean density (no. $\mathrm{m}^{-2} \times 10^{3}$ ) of Diporeia spp. in southern Lake Michigan. Small crosses denote sampling sites. (a) 1992 , (b) 1993, (c) 1998, (d) 1999, (e) 2000, (f) 2001, (g) 2002.

(a)
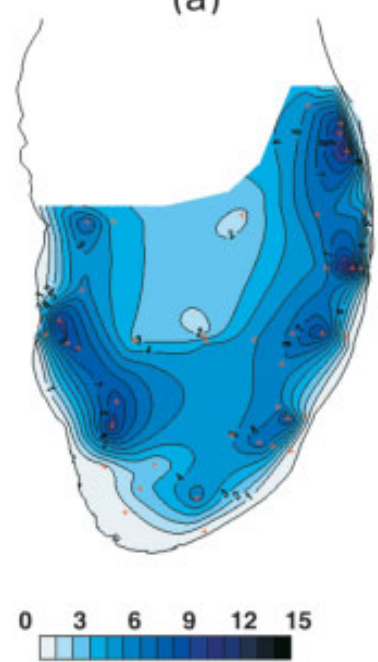

Density $\left(\right.$ no. $\left.\cdot \mathrm{m}^{-2} \times 10^{3}\right)$ (b)
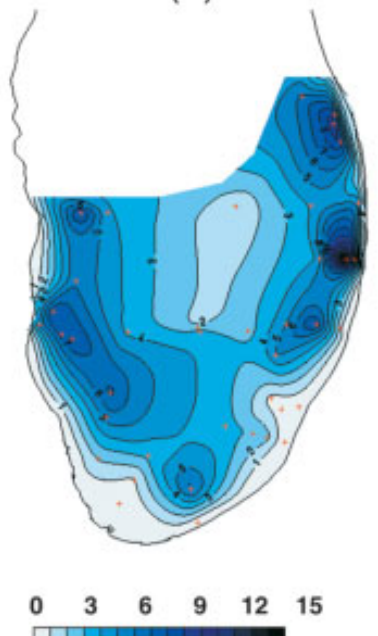

Density $\left(\right.$ no. $\left.\cdot \mathrm{m}^{-2} \times 10^{2}\right)$ (c)
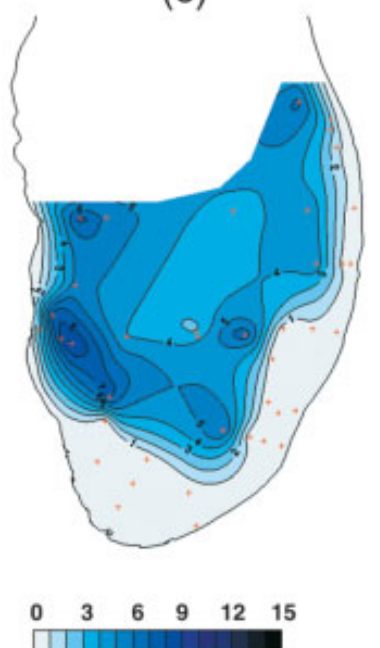

Density (no. $\left.\mathrm{m}^{-2} \times 10^{3}\right)$ (d)

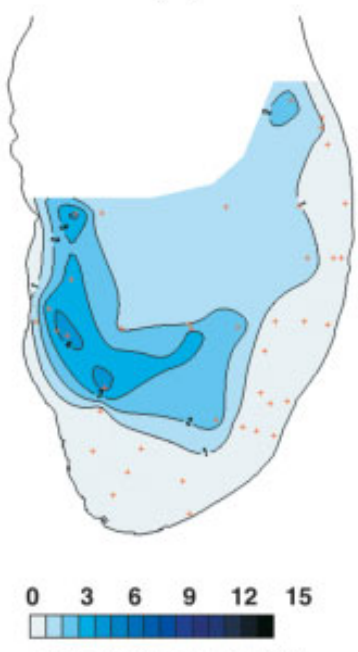

Density (no. $\left.\mathrm{m}^{-2} \times 10^{3}\right)$ (e)

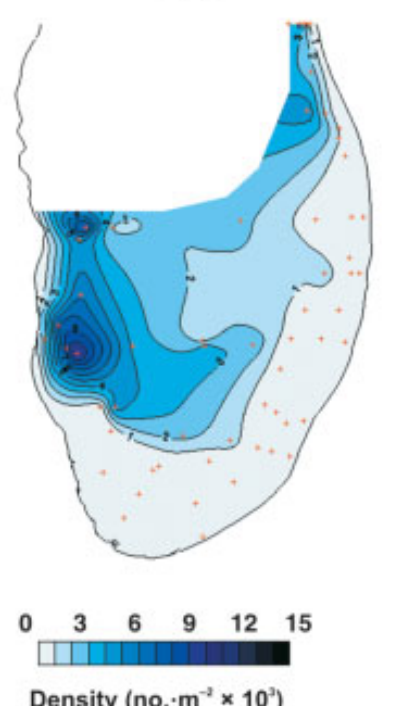

Density $\left(\right.$ no. $\left.\cdot \mathrm{m}^{-2} \times 10^{3}\right)$ (f)

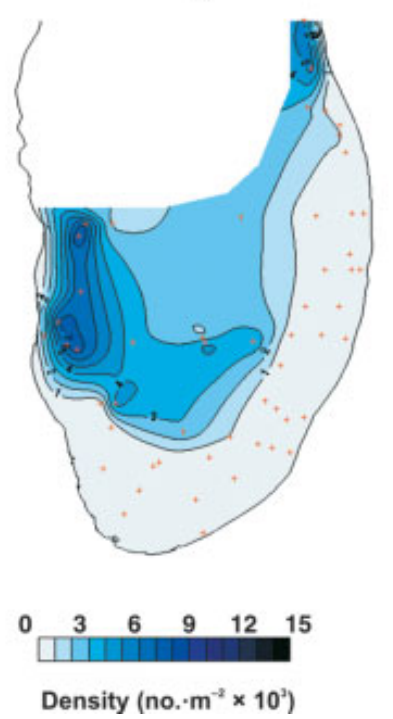

(g)

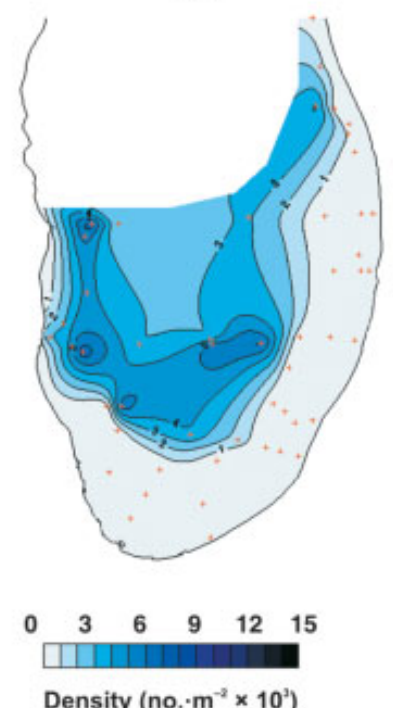

Density (no. $\left.\cdot \mathrm{m}^{-2} \times 10^{3}\right)$ prior to initial declines and total disappearance. Densities of Diporeia and Dreissena were not well correlated at H-22; the population at this site collapsed in 1992 and totally disappeared by 1997 , but Dreissena was not found at this site until 2000 (Table 3). At H-31 the relationship between the two taxa over the 1992-1999 period was not significant (linear regression; $R^{2}=0.37, P=0.11$ ), but the residuals indicated the presence of autocorrelation (Durbin-Watson $D$ statistic $=0.966)$. Further analysis with a 1-year time lag $(t-1)$ in Dreissena densities provided a significant relationship $\left(R^{2}=0.70, P=0.02\right.$, Durbin-Watson $D$ statistic $\left.=1.97\right)$. The relationship was improved when data from M-45 was included (Fig. 6).

\section{Recruitment and age classes, $45 \mathrm{~m}$ sites}

Because of limited availability of seasonal, size frequency data collected prior to declines at H-22 and SAU-45, meaningful analysis of density trends in the various age classes was only possible for populations at $\mathrm{H}-31$ and $\mathrm{M}-45$. As noted, declines in population density at H-31 were initially observed in 1994. Based on relative densities of YOY, juveniles, and adults, lower density in this year was a result of poor recruitment. Mean annual density of YOY in 1994 was only $215 \cdot \mathrm{m}^{-2}$ (seasonal peak $=406 \cdot \mathrm{m}^{-2}$ ) compared with a range of $920-2438 \cdot \mathrm{m}^{-2}$ (seasonal peak $=2411-4895 \cdot \mathrm{m}^{-2}$ ) in 1986-1993. In contrast, mean densities of juveniles and adults in 1994 were within the range found in 1986 to 1993 - 
Fig. 3. Mean density (no. $\mathrm{m}^{-2} \times 10^{3}$ ) of Diporeia spp. throughout Lake Michigan. Small crosses denote sampling sites. (a) 1994-1995, (b) 2000 .

(a)
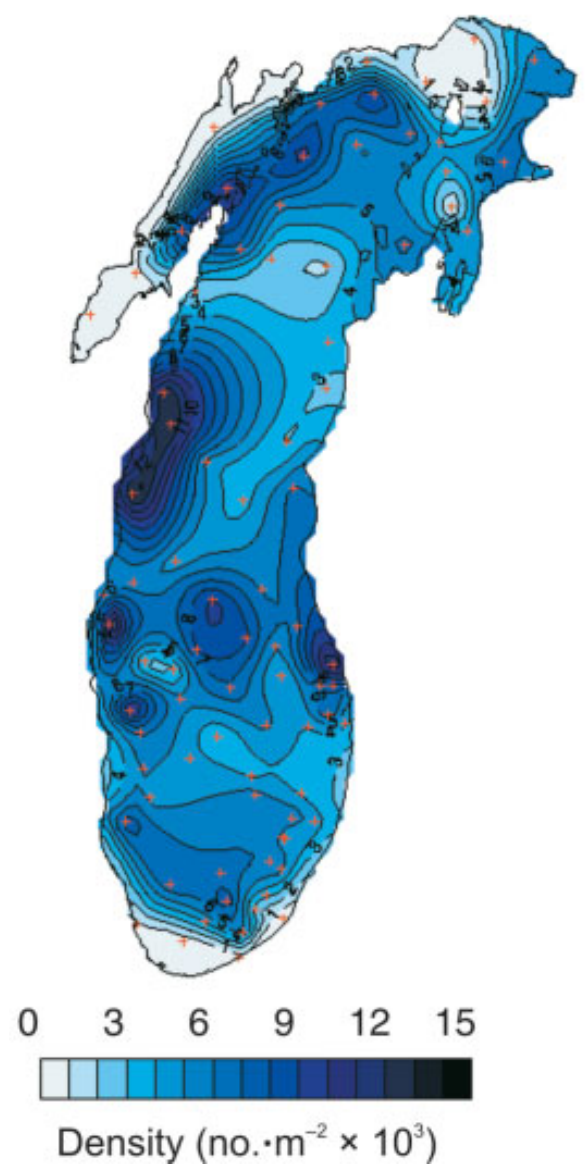

juvenile density was $3860 \cdot \mathrm{m}^{-2}$ in 1994 compared with $2004-$ $4283 \cdot \mathrm{m}^{-2}$ in $1986-1993$, and adult density was $3588 \cdot \mathrm{m}^{-2}$ in 1994 compared with $3462-7173 \cdot \mathrm{m}^{-2}$ in $1986-1993$. Considering Diporeia have a 2-year life cycle at this depth in southeastern Lake Michigan (Winnell and White 1984), the lack of recruitment in 1994 likely accounted for lower juvenile densities observed in 1995 (Fig. 7). Recruitment in 1995-1997 was generally similar to recruitment in 19861993, as strong peaks in YOY occurred in $1995\left(2438 \cdot \mathrm{m}^{-2}\right)$ and $1997\left(2640 \cdot \mathrm{m}^{-2}\right)$, and although we only sampled on one date in 1996 (July), a relatively high density of YOY $\left(2202 \cdot \mathrm{m}^{-2}\right)$ indicated recruitment also occurred in that year. Despite good recruitment, juvenile densities in these 3 years remained lower than found in 1986-1994, indicating poor YOY survival. Juvenile densities at H-31 subsequently collapsed in 1997 , declining from $3300 \cdot \mathrm{m}^{-2}$ in early spring to $150 \cdot \mathrm{m}^{-2}$ in late fall. Adult densities remained stable in 1997 but declined in 1998, most likely a result of the lack of juveniles the previous year.

At M-45, annual recruitment occurred between 1997 and 2002, and peaks in YOY densities ranged from $1200 \cdot \mathrm{m}^{-2}$ to $4700 \cdot \mathrm{m}^{-2}$ (Fig. 8). Yet despite recruitment, juvenile densities generally declined each year, again indicating poor YOY survival. The exception to this pattern occurred in 1999. (b)

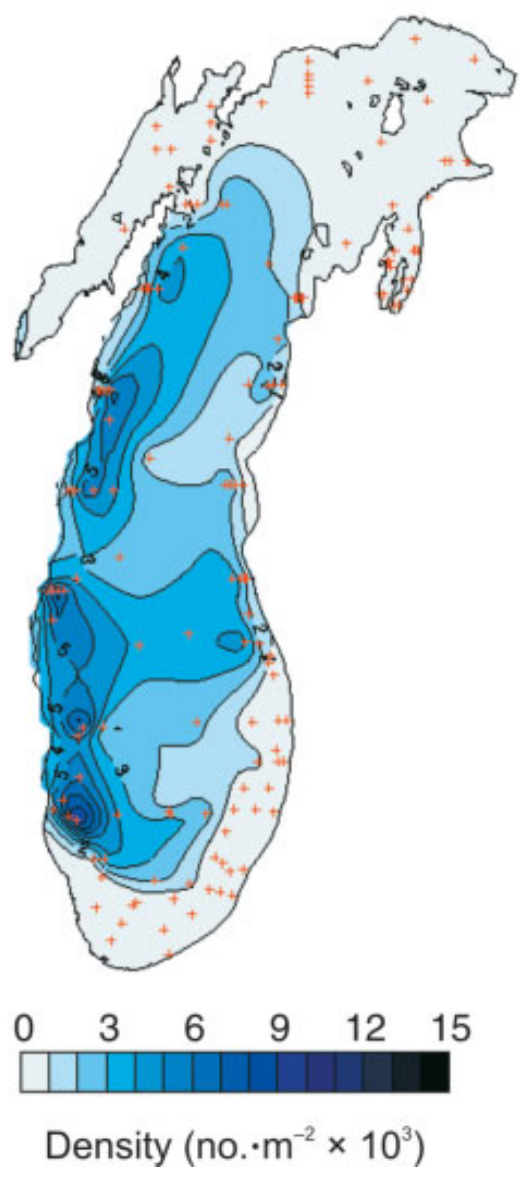

YOY survival was high in 1999 as evidenced by an increase in juvenile densities throughout the year, peaking at $3500 \cdot \mathrm{m}^{-2}$ in November; this accounted for the increase in population density in that year (Fig. 5). Juveniles continued to grow and survive through winter 2000 as evidenced by high adult density in spring $2000\left(4000 \cdot \mathrm{m}^{-2}\right)$. Recruitment occurred in 2000, but as in 1997 and 1998, these recruits did not survive to become juveniles.

The number of eggs per gravid female was determined in spring 2001 at M-45 to determine if brood size had declined since the 1980s. In a 1981 study at a $42 \mathrm{~m}$ site in southeastern Lake Michigan, Winnell and White (1984) found that brood size ranged from 10 to 25 eggs per female and was directly related to female size. Brood size in 2001 varied from 21 to 32 eggs per gravid female $(n=7)$ and fit the same functional relationship to female size as in 1981 .

\section{Lipid content and length-weight, $45 \mathrm{~m}$ sites}

When densities at the $45 \mathrm{~m}$ sites were declining, lipid content of juvenile and adult Diporeia tended to increase (Fig. 9). Detailed analysis of trends between density and lipid content were restricted to M-45, since densities at the other $45 \mathrm{~m}$ sites were already declining prior to 1997 . Between 1997 and 2001, there was a significant difference 
Table 2. Mean ( \pm standard error) densities $\left(\right.$ no. $\cdot \mathrm{m}^{-2}$ ) of Diporeia and Dreissena at four depth intervals in Lake Michigan in three different regions in 1994-1995 and 2000.

\begin{tabular}{|c|c|c|c|c|}
\hline \multirow[b]{2}{*}{ Lake region } & \multicolumn{2}{|l|}{ Diporeia } & \multicolumn{2}{|l|}{ Dreissena } \\
\hline & 1994-1995 & 2000 & 1994-1995 & 2000 \\
\hline \multicolumn{5}{|l|}{$<30 \mathrm{~m}$} \\
\hline South $(7,11)$ & $3488 \pm 1842$ & $207 \pm 205$ & $414 \pm 132$ & $617 \pm 340$ \\
\hline Central $(2,16)$ & $2173 \pm 2852$ & $1794 \pm 655$ & $0 \pm 0$ & $2541 \pm 848$ \\
\hline North $(9,20)$ & $2897 \pm 1156$ & $77 \pm 34$ & $926 \pm 921$ & $2025 \pm 594$ \\
\hline Overall & $3124 \pm 916$ & $692 \pm 252$ & $623 \pm 457$ & $1871 \pm 399$ \\
\hline \multicolumn{5}{|l|}{ 31-50 m } \\
\hline South $(6,20)$ & $6306 \pm 1454$ & $1194 \pm 561$ & $48 \pm 42$ & $589 \pm 338$ \\
\hline Central $(2,11)$ & $10477 \pm 4088$ & $4702 \pm 1210$ & $89 \pm 82$ & $629 \pm 217$ \\
\hline North $(5,16)$ & $4462 \pm 2150$ & $100 \pm 39$ & $528 \pm 528$ & $2268 \pm 1353$ \\
\hline Overall & $6249 \pm 1243$ & $1642 \pm 444$ & $239 \pm 201$ & $1170 \pm 489$ \\
\hline \multicolumn{5}{|l|}{ 51-90 m } \\
\hline South $(20,15)$ & $5285 \pm 423$ & $2742 \pm 932$ & $<1 \pm<1$ & $6 \pm 4$ \\
\hline Central $(5,19)$ & $11997 \pm 1189$ & $4691 \pm 487$ & $0 \pm 0$ & $32 \pm 16$ \\
\hline North $(6,12)$ & $6262 \pm 925$ & $893 \pm 414$ & $0 \pm 0$ & $7 \pm 5$ \\
\hline Overall & $6550 \pm 570$ & $3064 \pm 437$ & $<1 \pm<1$ & $17 \pm 7$ \\
\hline \multicolumn{5}{|l|}{$>90 \mathrm{~m}$} \\
\hline South $(9,6)$ & $4466 \pm 335$ & $2814 \pm 570$ & $0 \pm 0$ & $0 \pm 0$ \\
\hline Central $(9,6)$ & $4443 \pm 627$ & $2818 \pm 836$ & $0 \pm 0$ & $0 \pm 0$ \\
\hline North $(5,5)$ & $5007 \pm 1567$ & $754 \pm 459$ & $0 \pm 0$ & $0 \pm 0$ \\
\hline Overall & $4567 \pm 414$ & $2209 \pm 429$ & $0 \pm 0$ & $0 \pm 0$ \\
\hline
\end{tabular}

Note: See Nalepa et al. (2000) for delineation of regions. Values in parenthesis are numbers of sites sampled in 1994-1995 and 2000, respectively, within each depth interval and lake region. In 19941995, all Dreissena were D. polymorpha; in 2000, $98.3 \%$ were D. polymorpha and $1.7 \%$ were $D$. bugensis.

between years $\left(F_{[5,681]}=62.41, P=0.0001\right)$, age classes $\left(F_{[2,681]}=10.62, P=0.0001\right)$, and year $\times$ age class interaction $\left(F_{[13,681]}=10.60, P=0.0001\right)$. Yearly means in 1999 2001 were significantly higher than those in 1997-1998 $(P=$ 0.0001 , Tukey's HSD), and lipid content in juveniles and adults were significantly higher than those in YOY $(P=$ 0.0001 Tukey's HSD). When just considering juveniles and adults, lipid levels increased from $21.6 \% \pm 0.42 \%$ in $1997-$ 1998 to $28.7 \% \pm 0.56 \%$ in $1999-2001$. Similarly, as densities declined at H-31 between 1997 and 1999, mean adult lipid content increased from $23.9 \% \pm 0.6 \%$ in 1997 to $34.7 \% \pm 2.1 \%$ in 1999 . The relationship between lipid content and density can be put into a more long-term perspective by examining trends at H-31 beginning in the 1980 s (Fig. 4). Seasonal trends in lipid content of adult Diporeia were measured at this site in 1984, 1986, 1988, and 1989 (Gardner et al. 1985b; Gauvin et al. 1989; Cavaletto et al. 1996). Mean annual lipid content in 1984-1989 varied from $26 \%$ to $32 \%$. When density declines were first observed in 1994, mean lipid content was only $15 \%$. As densities continued to decline after 1994, lipid content increased each successive year until by 1998-1999 lipid values were as high as found in the 1980s.

Lipid content in juveniles and adults generally peaked in spring or summer and then declined in fall (Fig. 9). Seasonal peaks in late spring - summer were consistent with the premise that intensive feeding during the spring diatom bloom results in the storage of energy as lipids (Gardner et al. 1985b, 1990). To determine if seasonal peaks in 1997-
2001 were comparable with those found in 1984-1989 (adults only), the seasonal maximum was divided by the early spring minimum and the ratio was compared between the two periods. For the 1997-2001 period, only those sites and years in which adults were collected throughout the year were included. The mean ratio was $1.31 \pm 0.07(n=8)$ in 1997-2001 and $1.58 \pm 0.28(n=4)$ in 1984-1989. Although lower in the 1997-2001 period, the difference was not significant ( $t$ test; $P>0.05$ ).

In deepwater amphipods, weight per unit length generally declines when animals are food-limited (Hill et al. 1992; Lehtonen 1996). The relationship between lipid-free dry weight (LFDW in $\mathrm{mg}$ ) and length ( $L$ in $\mathrm{mm}$ ) was defined by LFDW $=a L^{b}$ and was determined annually for each $45 \mathrm{~m}$ site over the 1994-2001 period (Table 4). All regressions were significant (range of $R^{2}: 0.56-0.96$ ). When LFDW for a standard $5 \mathrm{~mm}$ animal was calculated, yearly trends were not apparent (Table 4).

\section{Sedimentation rates and sediment variables}

Sediment traps, deployed at the $45 \mathrm{~m}$ sites in 1997-1999, documented amounts of organic material settling to the bottom that potentially served as a food source for Diporeia. In general, there was a consistent primary peak of TOC, BiS, and $\mathrm{Chl}$ in spring and a secondary peak in fall at each of the sites (Fig. 10). Most relevant to Diporeia populations were flux rates associated with the spring peaks; these peaks are enriched in organic materials (diatoms) compared with peaks in the fall (Scavia and Fahnenstiel 1987; Gardner et al. 
Fig. 4. Density $\left(\right.$ no. $\cdot \mathrm{m}^{-2}$ ) of Diporeia spp. at three $45 \mathrm{~m}$ sites in southeastern Lake Michigan, 1980-2002: (a) H-31, (b) SAU-45, (c) H-22. The broken lines at H-31 give the lipid content (percent dry weight) of Diporeia spp. at this site.
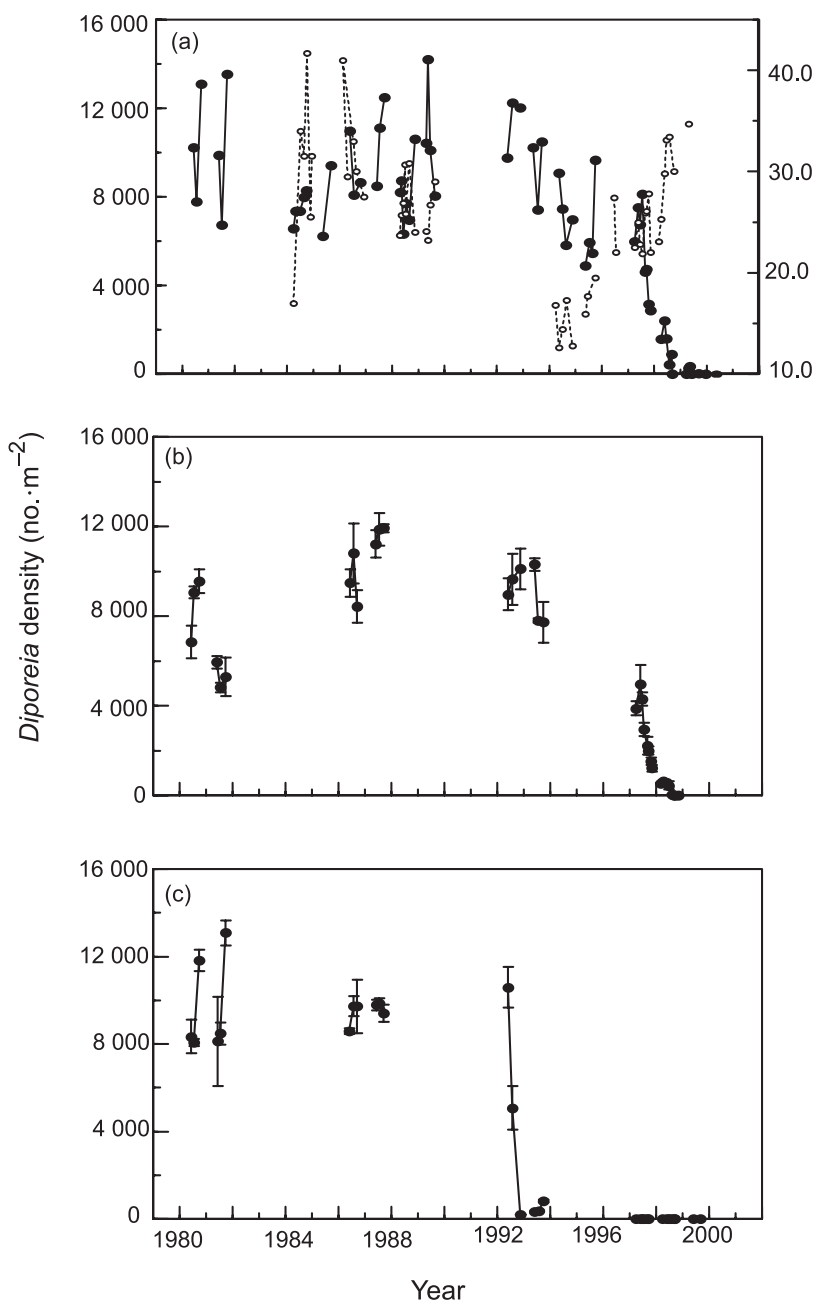

1989). Over the 1997-1999 period, the magnitude of spring peaks at H-31 and M-45 decreased for all constituents (Fig. 10). In spring 1997, the spring average (March-May) flux rates of TOC at these two sites were 434 and $461 \mathrm{mg} \cdot \mathrm{m}^{-2} \cdot \mathrm{day}^{-1}$, respectively, and flux rates of BiS were 1176 and $1199 \mathrm{mg} \cdot \mathrm{m}^{-2} \cdot \mathrm{day}^{-1}$, respectively. In contrast, spring 1999 flux rates of TOC were only 88 and $57 \mathrm{mg} \cdot \mathrm{m}^{-2} \cdot$ day $^{-1}$, and flux rates of BiS were 181 and $45 \mathrm{mg} \cdot \mathrm{m}^{-2} \cdot \mathrm{day}^{-1}$, respectively, for sites H-31 and M-45. Low flux rates in 1999 were mostly related to quantitative changes in inputs, as nutrient content of collected material was generally higher in 1999 than in previous years (Table 5). Further, mean annual $\mathrm{C} / \mathrm{N}$ ratio (weight) did not show a consistent trend at these two sites over the same period; the ratio tended to increase at M45 but not at H-31. In 1998 when flux rates were measured at all four $45 \mathrm{~m}$ sites, spring average flux rates of all constituents increased on a spatial gradient from south to north, being lowest at H-22 and highest at M-45 (Fig. 10), while the mean $\mathrm{C} / \mathrm{N}$ ratio decreased along the same gradient (Table 5).

Sediment composition varied widely at the $45 \mathrm{~m}$ sites, ranging from predominately silt at the southern-most site (H-22) to sand at the northern-most site (M-45). The percent
Table 3. Mean ( \pm standard error) density $\left(\right.$ no. $\cdot \mathrm{m}^{-2}$ ) of Dreissena at the $45 \mathrm{~m}$ sites in southeast Lake Michigan, 1992-2002.

\begin{tabular}{|c|c|c|c|c|}
\hline \multirow[b]{2}{*}{ Year } & \multicolumn{4}{|c|}{ Station } \\
\hline & H-22 & SAU-45 & H-31 & M-45 \\
\hline 1992 & $0 \pm 0$ & $0 \pm 0$ & $3 \pm 2$ & - \\
\hline 1993 & $0 \pm 0$ & $0 \pm 0$ & $14 \pm 9$ & - \\
\hline 1994 & - & - & $39 \pm 14$ & - \\
\hline 1995 & - & - & $50 \pm 16$ & - \\
\hline 1996 & - & - & 143 & - \\
\hline 1997 & $0 \pm 0$ & $30 \pm 17$ & $669 \pm 261$ & $616 \pm 367$ \\
\hline 1998 & $0 \pm 0$ & $966 \pm 897$ & $2561 \pm 853$ & $1044 \pm 525$ \\
\hline 1999 & $0 \pm 0$ & 21 & $2581 \pm 209$ & $2235 \pm 1075$ \\
\hline 2000 & 21 & 136 & 171 & $836 \pm 459$ \\
\hline 2001 & 0 & 0 & 5576 & $1046 \pm 646$ \\
\hline 2002 & 29 & 464 & 1699 & $835 \pm 376$ \\
\hline
\end{tabular}

Note: Standard errors depict variability between sampling dates.

Fig. 5. Mean density (no. $\mathrm{m}^{-2}$ ) of Diporeia spp. on each sampling date at three $45 \mathrm{~m}$ sites in 1997-2002. Although not shown, no Diporeia were collected at the other $45 \mathrm{~m}$ site $(\mathrm{H}-22)$ during the sampling period. Error bars denote standard error. $\triangle$, SAU-45; O, H-31;, $\mathrm{M}-45$.

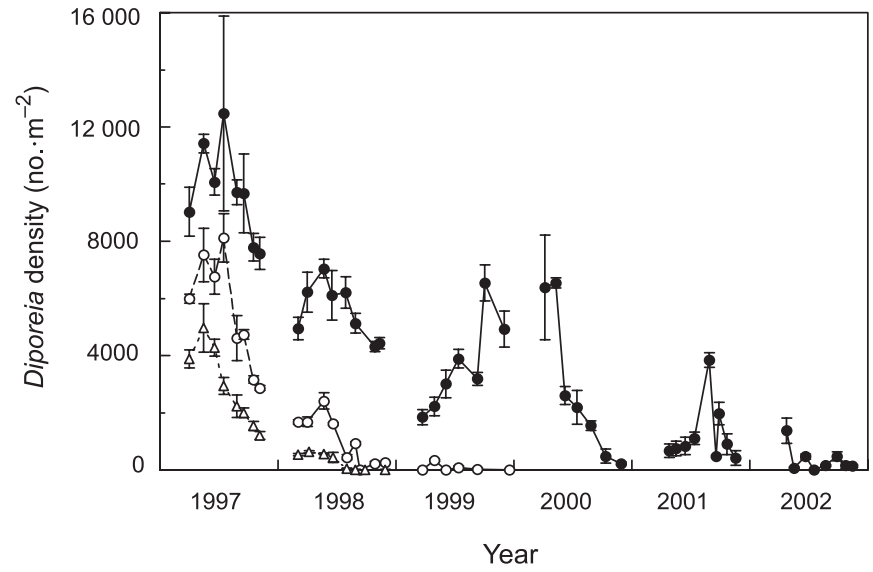

Fig. 6. Relationship between mean annual density $\left(\right.$ no. $\left.\cdot \mathrm{m}^{-2}\right)$ of Diporeia spp. and Dreissena at H-31 (०) and M-45 (○). Dreissena densities are given as a 1-year time lag $(t-1)$. Sampling periods were 1992-1999 for H-31 and 1997-2002 for M45 (linear regression $R^{2}=0.59, P=0.003, n=12$ ).

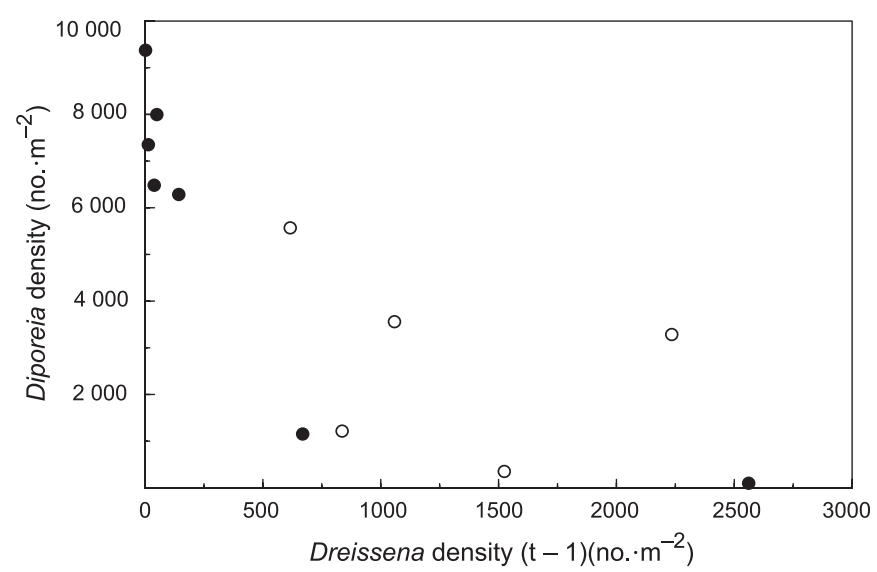


Fig. 7. Density $\left(\right.$ no. $\cdot \mathrm{m}^{-2}$ ) of three life stages of Diporeia spp. at H-31 in 1986-1999: (a) young-of-year, (b) juveniles, (c) adults.
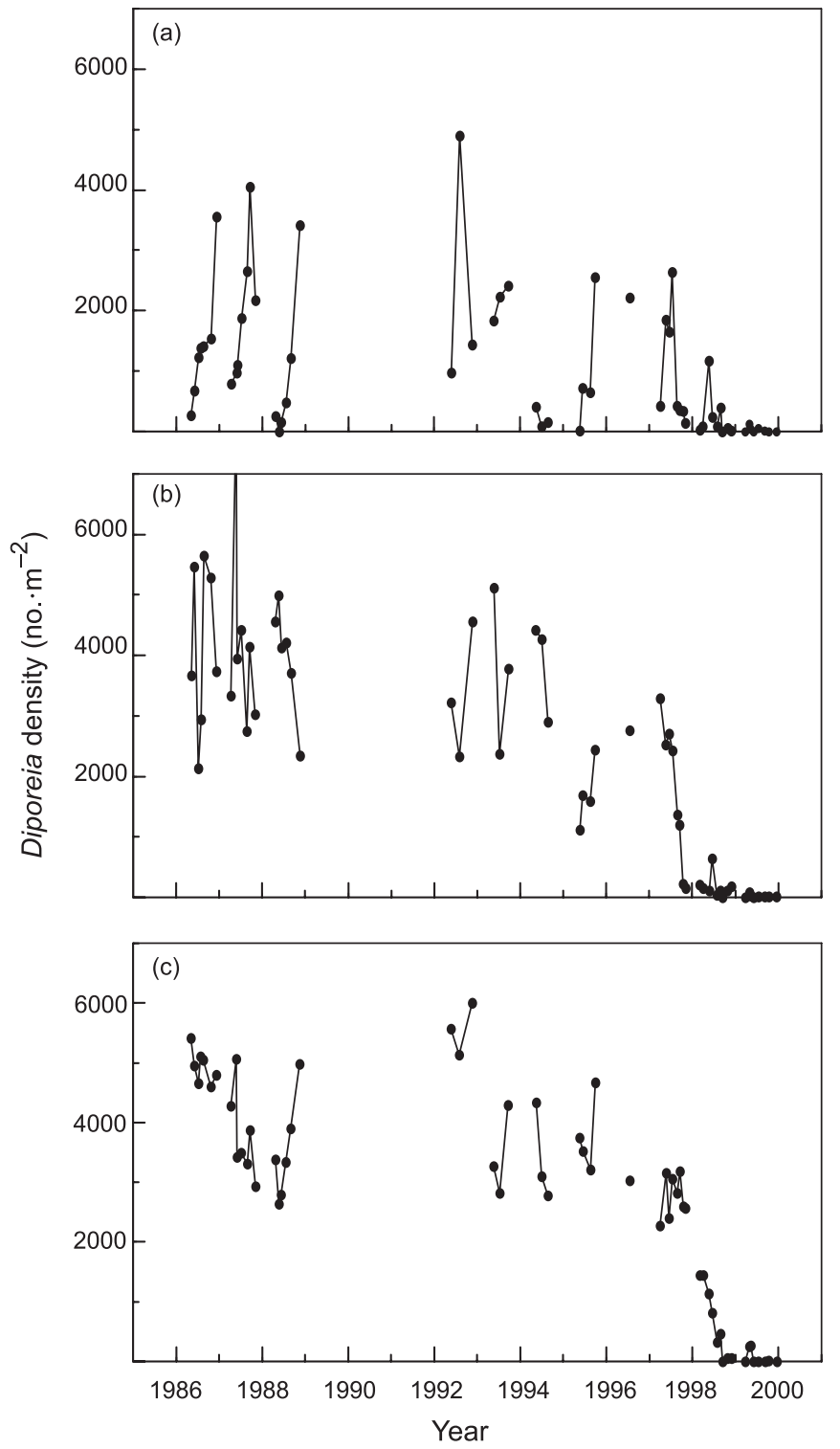

clay, silt, and sand was, respectively, $2.3 \%, 85.7 \%$, and $12.0 \%$ at $\mathrm{H}-22 ; 1.9 \%, 53.2 \%$, and $44.9 \%$ at SAU-45; $1.7 \%$, $31.3 \%$, and $67.0 \%$ at $\mathrm{H}-31$; and $0.7 \%, 15.2 \%$, and $84.1 \%$ at M-45. Nutrient content of the upper $0-1 \mathrm{~cm}$ decreased from south to north as grain size increased. In 1998 mean sediment concentrations of TOC, BiS, and Chl were 4-, 6-, and 3.5-times greater, respectively, at $\mathrm{H}-22$ than at $\mathrm{M}-45$ (Table 5). Continued sampling at H-31 to 2000 and at M-45 to 2002 indicated nutrient content increased over levels found in 1998. At H-31 there was a significant difference between years $(1998-2000)$ for $\operatorname{BiS}\left(F_{[2,11]}=4.406, P=0.039\right)$, and at M-45 there was a significant difference between years (1998-2002) for TOC $\left(F_{[4,29]}=12.43, P=0.0001\right)$, BiS $\left(F_{[4,29]}=18.77, P=0.0001\right)$, and $\mathrm{CHl}\left(F_{[4,29]}=11.122, P=\right.$ $0.0001)$. The increase at M-45 was such that in 2002, concentrations of BiS and $\mathrm{Chl}$ were not significantly different from values found at $\mathrm{H}-22$ in 1998 ( $t$ test, df $=15, P=0.239$
Fig. 8. Density $\left(\right.$ no. $\cdot \mathrm{m}^{-2}$ ) of three life stages of Diporeia spp. at M-45 in 1997-2001: (a) young-of-year, (b) juveniles, (c) adults.
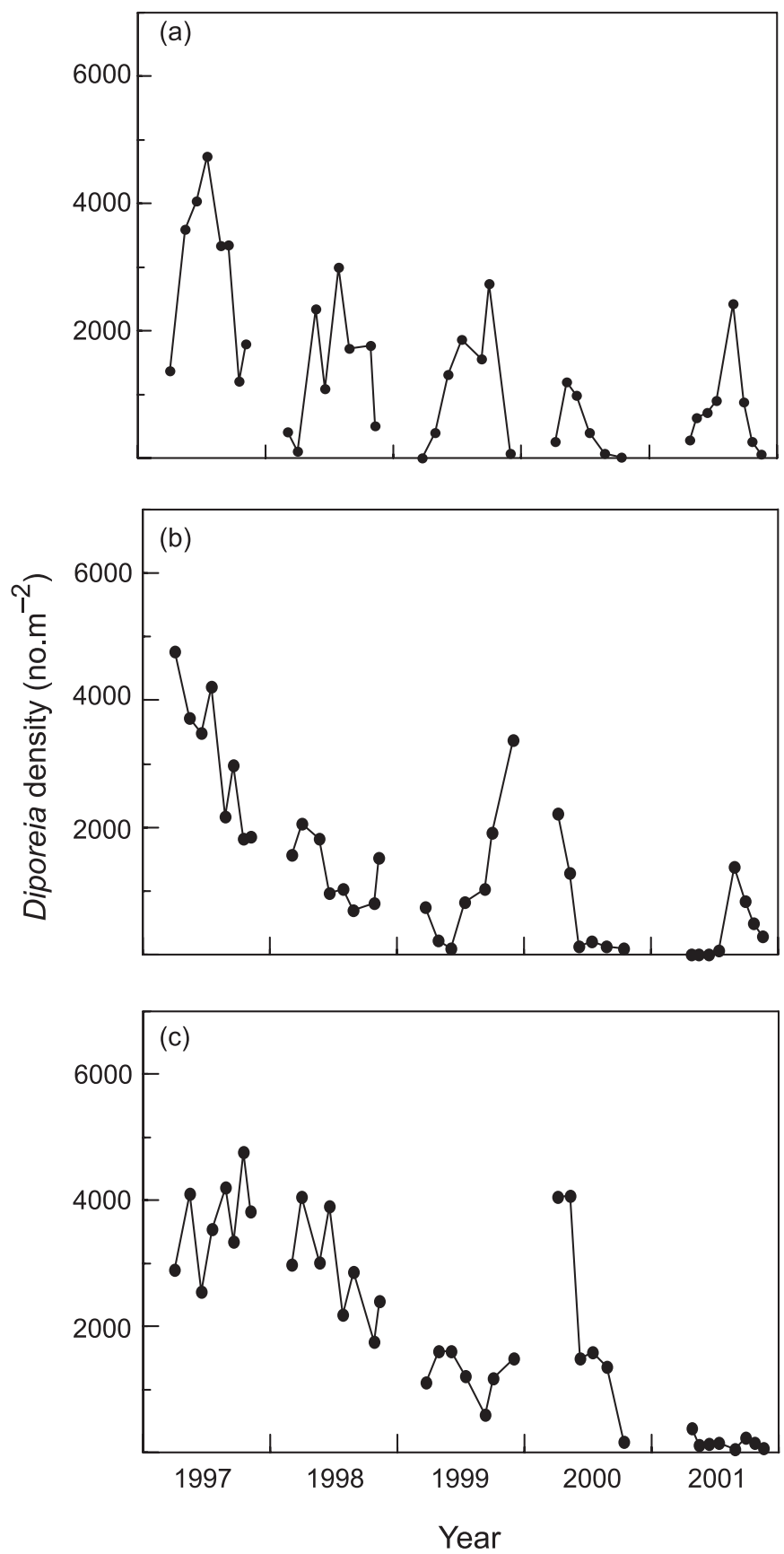

for BiS; $P=0.79$ for $\mathrm{Chl})$. As nutrient content increased, there was no apparent trend in the $\mathrm{C} / \mathrm{N}$ ratio (Table 5).

\section{Laboratory experiments}

Mortality in the 66-day starvation experiments was low in all four treatments. Of the 191 animals retrieved from filtered lake water, ashed sand, H-31 sediments, and M-45 sediments, only five were found dead during the entire experimental period. Lipid content declined in all four treatments during the experimental period (Table 6). Mean initial lipid content was $31.8 \%$ on day 0 , and final lipid content ranged from $21.3 \%$ ( $\mathrm{H}-31$ sediment) to $25.2 \%$ (sand) on day 
Fig. 9. Mean lipid content (percent dry weight) of young-of-year $(+--+)$, juvenile $(\bigcirc--\bigcirc)$, and adult $(\bigcirc-\bigcirc)$ Diporeia spp. at three 45 m sites in 1997-2001: (a) M-45, (b) H-31, (c) SAU- 45.
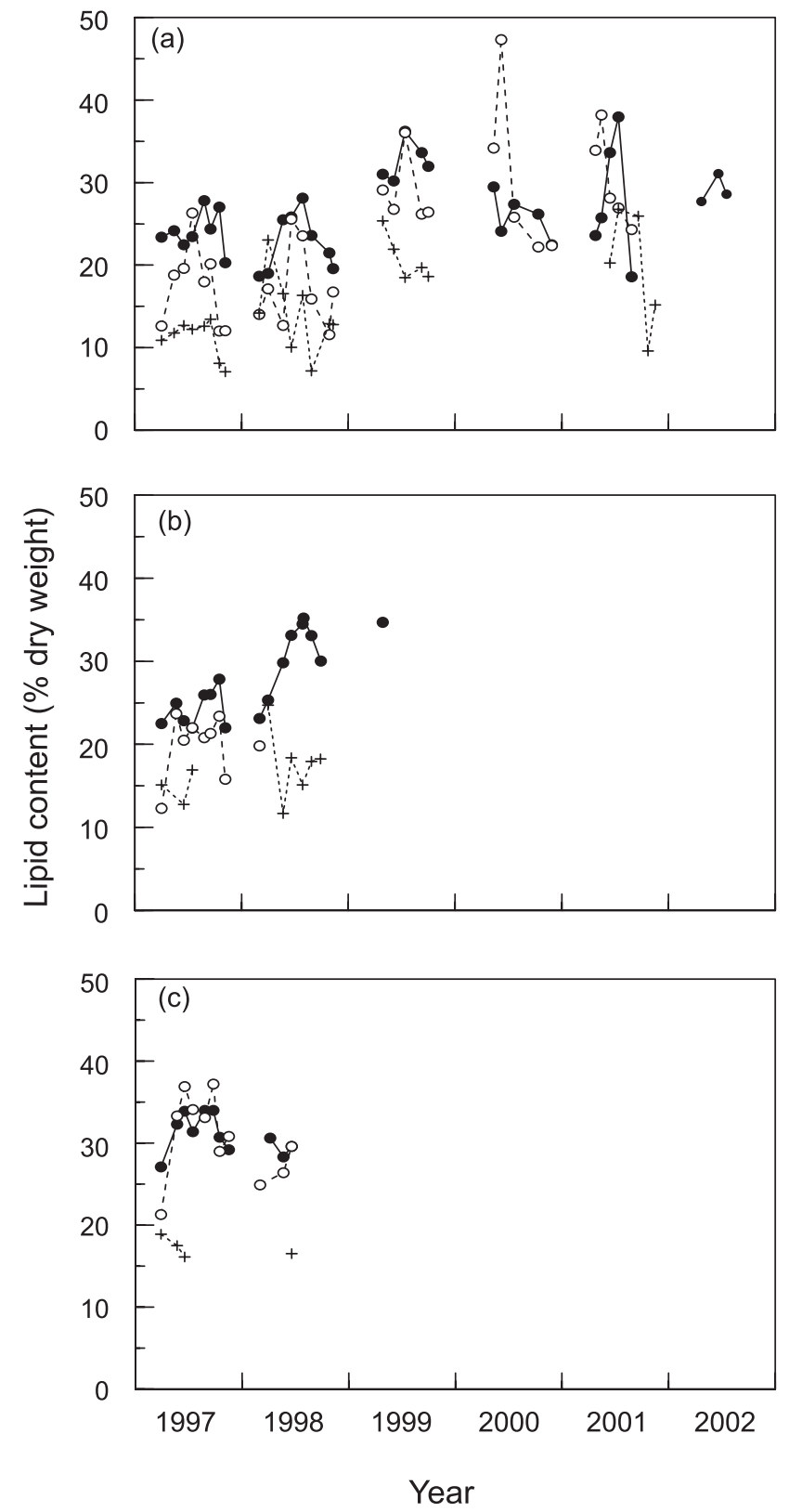

66. There was a significant difference between dates $\left(F_{[4,109]}=6.46, P=0.0001\right)$, but date $\times$ treatment interaction was not significant $\left(F_{[12,109]}=0.95, P=0.50\right)$, indicating no difference in treatment effects. On the date experiments ended (16 July), mean lipid content of freshly collected adults at M-45 was $27.4 \%$. The greater lipid value of in situ animals suggested access to nutritional material not available to laboratory animals.

In the preference-avoidance experiments, 95 of 100 and 92 of 100 animals were recovered in the two trials, respectively. Mortality was minimal (only 6 of 187), and all living animals were found burrowed in the substrate rather than swimming in the overlying waters. Mean ( \pm standard error, $\mathrm{SE}$ ) numbers of animals burrowed in sand, H-31 sediment, and M-45 sediment were $0 \pm 0,14.5 \pm 2.5$, and $15.7 \pm 3.5$, respectively. Numbers found in the two sediment treatments were not significantly different, and numbers in both sediment treatments were significantly higher than numbers found in the sand treatment $\left(F_{[2,15]}=12.268, P=0.001\right.$, Tukey's HSD). When sediments for these experiments were collected (July 2000), the Diporeia population had already disappeared from $\mathrm{H}-31$, but was still present at M-45. Given these laboratory results, the disappearance from $\mathrm{H}-31$ was not likely due to animals actively avoiding the sediments per se.

\section{Discussion}

On a broad scale, the decline of Diporeia in Lake Michigan in the 1990s was closely related to the expansion of dreissenid populations within the lake. In the southern basin, greatest declines occurred in the 30-50 m depth interval where dressenid densities increased to the greatest extent. Also, declines lakewide were most extensive in the northern portion of the lake where dreissenid densities were higher than in more southern portions. Yet on a local scale, inconsistencies were apparent. Whereas Diporeia and dreissenids were negatively correlated at several sites, Diporeia remained abundant at some sites despite the long-term presence of dreissenids, but yet declined rapidly at a site with no dreissenids. Our field observations and laboratory experiments failed to establish a clear, direct relationship between the loss of Diporeia and indicators of food availability. From our results, several questions pertinent to the food-limitation hypothesis remain enigmatic. (i) Why did the Diporeia population collapse so completely in an area where there were no mussels and where at least some pelagic food material was still likely settling to the benthic region? (ii) Why did lipid content, which is an indicator of energy reserves and directly related to food availability, remain at high levels as the population disappeared?

In areas where dreissenids were not present or found in low numbers, such as at H-22, sediment traps should accurately reflect pelagic inputs to the upper sediments. That is, mussels at the sediment surface would not be intercepting settling organic material prior to becoming available to Diporeia feeding in the upper sediments. Diporeia at H-22 completely disappeared by 1997 , yet based on trap flux rates of TOC, BiS, and Chl in 1998, at least some organic material was still settling to the bottom. Others have also documented a collapse of Diporeia populations in areas far removed from Dreissena colonies and where potential food was still found in the water column (Dermott 2001; Nalepa et al. 2003). Dermott (2001) theorized that the remote loss of Diporeia might be a function of their spatial distributions relative to dreissenid beds and dominant current patterns. Particulate organic material in water flowing over dreissenid beds would be removed by mussel filtration and unavailable to Diporeia located in areas downcurrent. In the Hudson River, Strayer and Smith (2001) suggested that the upstream removal of organic material by dense dreissenid colonies led to the severe decline of microzooplankton in areas downstream with few mussels. This, in turn, led to the extirpation of downstream Chaoborus populations, which relied on microzooplankton as a food source. Even so, it is difficult to reconcile how the remote removal of potential food by 
Table 4. Relationship between lipid-free dry weight and length for Diporeia at each of the $45 \mathrm{~m}$ sampling sites in each year lipid content was measured.

\begin{tabular}{lllcll}
\hline Year & $a$ & $b$ & $n$ & $R^{2}$ & $5 \mathrm{~mm}$ \\
\hline SAU-45 & & & & & \\
1997 & $-4.497(0.092)$ & $2.484(0.053)$ & 195 & 0.919 & 0.61 \\
1998 & $-4.880(0.155)$ & $2.660(0.081)$ & 73 & 0.939 & 0.55 \\
H-31 & & & & \\
1994 & $-2.374(0.194)$ & $1.227(0.114)$ & 94 & 0.558 & 0.67 \\
1995 & $-4.332(0.208)$ & $2.138(0.113)$ & 60 & 0.861 & 0.41 \\
1996 & $-3.946(0.338)$ & $1.910(0.169)$ & 43 & 0.756 & 0.42 \\
1997 & $-4.900(0.081)$ & $2.705(0.048)$ & 208 & 0.939 & 0.58 \\
1998 & $-4.499(0.147)$ & $2.472(0.081)$ & 149 & 0.865 & 0.59 \\
M-45 & & & & & \\
1997 & $-4.838(0.072)$ & $2.666(0.043)$ & 172 & 0.957 & 0.58 \\
1998 & $-5.086(0.064)$ & $2.732(0.038)$ & 205 & 0.962 & 0.50 \\
1999 & $-4.803(0.106)$ & $2.679(0.063)$ & 107 & 0.946 & 0.61 \\
2000 & $-5.222(0.309)$ & $2.833(0.181)$ & 97 & 0.721 & 0.52 \\
2001 & $-4.975(0.095)$ & $2.678(0.058)$ & 116 & 0.950 & 0.51 \\
\hline
\end{tabular}

Note: The relationship is defined by $\ln$ LFDW $=a+b \ln L$, where LFDW is lipid-free dry weight $(\mathrm{mg})$, and $L$ is body length $(\mathrm{mm})$. Standard error is given in parentheses. $n$ is the total number of animals analyzed. The lipid-free dry weight of a standard $5 \mathrm{~mm}$ animal is given.

dreissenids in shallow, nearshore regions can so effectively eliminate Diporeia populations from deeper depths in southeastern Lake Michigan. In this area of the lake, nearshoreoffshore transport of particulate material occurs mainly during storm events in the spring (Eadie et al. 2002). Dreissenid colonies can conceivably affect this transport process by retaining more organic matter in the nearshore zone, thus reducing deposition in offshore areas (Hecky et al. 2004). The role of nearshore transport compared with local pelagic inputs in supporting offshore Diporeia populations is unknown. Yet if nearshore retention of organic material by dreissenids was the reason for the total loss of Diporeia, then the population at $45 \mathrm{~m}$ must have been far more nutritionally dependent on inputs from the nearshore than pelagic inputs from the immediate overlying waters. This seems unlikely, since ingestion rates, assimilation rates, and lipid levels were closely linked to water column productivity at $45 \mathrm{~m}$ in the years prior to Dreissena (Fitzgerald and Gardner 1993; Gardner et al. 1989). In terms of food quality, C/N ratios of trap material and upper sediments at $\mathrm{H}-22$ were $10-13$, similar to the ratio of autochthonous matter produced by decomposed plankton (Wetzel 2001). Fresh algal material has a ratio of 6.7 (Redfield ratio). Ratios at H-22 were generally higher than ratios at the other $45 \mathrm{~m}$ sites, but below the threshold known to affect growth and development of some benthic detritivores (Soderstrom 1988; Dorgelo and Leonards 2001). While densities of deepwater amphipods are a function of fresh algal inputs (Johnson and Wiederholm 1992), the relationship between food quality and the survival of the population remains unclear. However, Diporeia have historically been the dominant benthic macroinvertebrate in the deepest regions of the Great Lakes where benthic food inputs are minimal and highly refractive. Further, the rapid decline at $\mathrm{H}-22$ was first observed after the spring period, which is inconsistent with the food-limitation hypothesis, since this is the period when food availability would be at a seasonal maximum.
The disappearance of Diporeia at H-31 and M-45 was more gradual (5 years) than at $\mathrm{H}-22$ and well correlated to an increase in the Dreissena population. Given this close temporal association, food limitation may indeed have played a major role in the loss of Diporeia at these sites. Yet flux rates of constituents indicative of food inputs during the period of initial declines were similar to rates reported prior to Dreissena. For instance, the population at $\mathrm{H}-31$ began to decline in 1994 and collapsed in 1997 and 1998, while the population at M-45 began to decline in 1997. In 1997 and 1998, average spring flux rates of TOC at these two sites varied from 273 to $461 \mathrm{mg} \cdot \mathrm{m}^{-2} \cdot \mathrm{day}^{-1}$, which were comparable with rates of 288 and $430 \mathrm{mg} \cdot \mathrm{m}^{-2} \cdot \mathrm{day}^{-1}$ found at $\mathrm{H}-31$ in 1986 and 1990, respectively (B.J. Eadie, unpublished data). Uncorrected mean spring flux rates of BiS in 1997-1998 were $433-1500 \mathrm{mg} \cdot \mathrm{m}^{-2} \cdot \mathrm{day}^{-1}$. These rates were generally similar to or greater than an uncorrected mean spring flux rate of $475 \mathrm{mg} \cdot \mathrm{m}^{-2}$. day ${ }^{-1}$ found at H-31 in 1986 (Gardner et al. 1989). Populations were already declining in 1999 when far lower flux rates of all constituents were observed. Low flux rates in 1999 were likely a result of an uncommon occurrence rather than the beginning of a trend. In most years, water column Chl peaks in spring, but in 1999, the peak occurred in early winter (B.J. Eadie, unpublished data). Thus, we likely missed the spring diatom peak with our deployment in 1999. As noted, sediment traps do not reflect pelagic inputs to the upper sediments in areas when Dreissena densities are high. Dreissena densities were $>500 \cdot \mathrm{m}^{-2}$ in 1997 at H-31 when the Diporeia population collapsed, but $<50 \cdot \mathrm{m}^{-2}$ in 1994 when initial declines were observed. Thus, despite high pelagic inputs that were still likely present in 1994, even low densities of Dreissena had a negative impact on Diporeia.

Our laboratory experiments indicated that sediments from H-31 and M-45 did not have an adverse impact on Diporeia per se. Mortality was not observed after a 66-day exposure, and the sediments were not actively avoided. Interestingly, 
Fig. 10. Flux rates for chlorophyll $a(\mathrm{Chl} a)$, total organic carbon (TOC), and biogenic silica (BiS) at the $45 \mathrm{~m}$ sites in 1997-1999: (a) M-45, (b) H-31, (c) SAU-45, (d) H-22. Rates were derived from material collected in sediment traps placed at 30 depth in the water column. The input from local resuspension was corrected for by subtracting local surface sediment concentrations from trap concentrations, then multiplying by the mass flux. Shaded areas indicate unstratified periods.
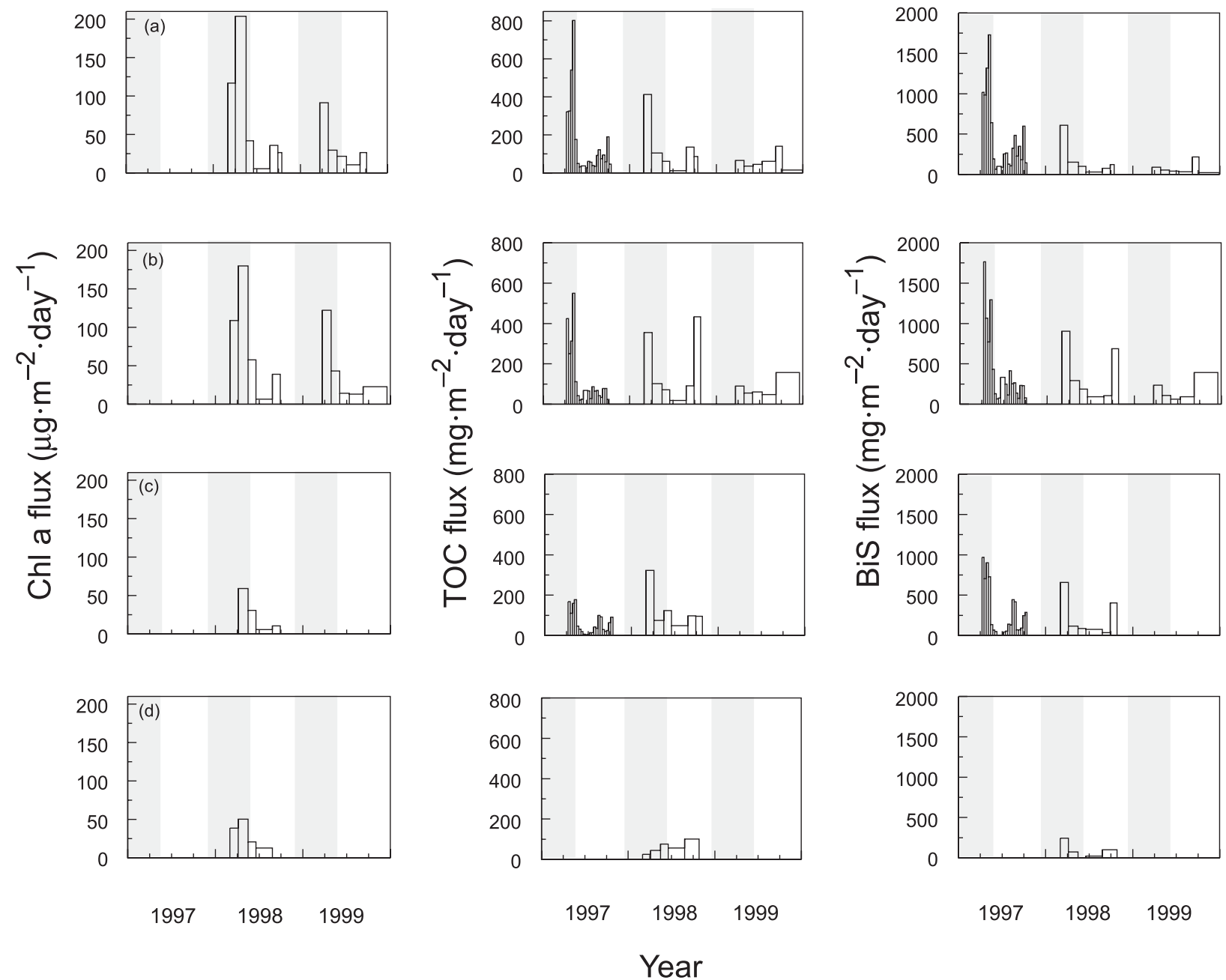

whereas there was no mortality during the laboratory experiments, the population of Diporeia at M-45 declined by $66 \%$ over the same 66-day period (May to July). Thus, conditions that led to the decline at M-45 were not duplicated in the laboratory using sediments from the same site and animals from the same population. This may imply that the population was reacting negatively en masse to the physical deposition of organic material in the spring. As noted, the rapid decline at H-22 was similarly observed after the spring period. Sediments from H-31 and M-45 were not acutely toxic to Diporeia, the same result found for sediments from $\mathrm{H}-22$ (Landrum et al. 2000).

If food limitation was the primary cause for the loss of Diporeia, then the animals should show some physiological signs of starvation before or during the period of population loss. In deepwater amphipods, lipid levels are a good indicator of food availability; levels increase just after the spring diatom bloom when food is readily available and decline during periods of low benthic food inputs in late summer and winter (Gardner et al. 1985b; Hill et al. 1992; Lehtonen 1996). When the population began to decline at H-31 in 1994, mean annual lipid content was only $15 \%$, and the spring lipid peak was only $17 \%$. These values indicate severe starvation - similar levels were found in laboratory animals starved for 120 days (Gauvin et al. 1989). Recruitment was poor in 1994, which is consistent with the suggestion that lipid values below $20 \%$ lead to reproductive failure (Hill et al. 1992). As densities continued to decline after 1994, lipid content unexpectedly increased and annual recruitment occurred. Possibly, lipid content increased because declining densities led to more food for remaining organisms. Yet if this were so, then poor YOY survival should not have occurred, and the population should have stabilized at some reduced level consistent with a diminished food supply. Further, the increase in dreissenids over this period would have further reduced available food and resulted in lower rather than higher lipid values. As Diporeia densities approached zero in 1999, lipid levels were over $30 \%$ and comparable with levels found at this site in the 1980s just after the spring diatom bloom (Gardner et al. 1985b; Cavaletto et al. 1996).

While the long-term decrease and then increase in lipid content found at $\mathrm{H}-31$ has not been previously documented in field populations, such a pattern was found in animals 
Table 5. Mean ( \pm standard error) annual concentrations of total organic carbon (TOC), biogenic silica (BiS), chlorophyll (Chl), and $\mathrm{C} / \mathrm{N}$ ratio (weight) in material collected in sedimentation traps and upper sediments $(0-1 \mathrm{~cm})$ at the $45 \mathrm{~m}$ sites.

\begin{tabular}{|c|c|c|c|c|c|c|c|c|}
\hline \multirow[b]{2}{*}{ Year } & \multicolumn{2}{|c|}{ TOC $\left(\mathrm{mg} \cdot \mathrm{g}^{-1}\right)$} & \multicolumn{2}{|l|}{$\mathrm{BiS}\left(\mathrm{mg} \cdot \mathrm{g}^{-1}\right)$} & \multicolumn{2}{|c|}{ Chl $\left(\mu \mathrm{g} \cdot \mathrm{g}^{-1}\right)$} & \multicolumn{2}{|l|}{$\mathrm{C} / \mathrm{N}$ ratio } \\
\hline & Trap & Sediment & Trap & Sediment & Trap & Sediment & Trap & Sediment \\
\hline \multicolumn{9}{|l|}{ M-45 } \\
\hline 1998 & $47.8 \pm 8.7$ & $4.7 \pm 0.3$ & $70.5 \pm 23.5$ & $2.6 \pm 0.3$ & $24.7 \pm 5.9$ & $1.1 \pm 0.2$ & $9.3 \pm 0.7$ & $7.7 \pm 0.4$ \\
\hline 1999 & $80.2 \pm 22.3$ & $4.9 \pm 0.4$ & $74.3 \pm 9.8$ & $3.1 \pm 0.5$ & $42.4 \pm 5.5$ & $1.7 \pm 0.2$ & $13.7 \pm 2.7$ & $8.8 \pm 0.7$ \\
\hline 2000 & - & $5.0 \pm 0.3$ & - & $2.1 \pm 0.6$ & - & $0.8 \pm 0.2$ & - & $8.5 \pm 0.3$ \\
\hline \multicolumn{9}{|l|}{ H-31 } \\
\hline 1997 & $37.2 \pm 2.7$ & $6.7 \pm 0.1$ & $108.6 \pm 11.8$ & - & - & - & $7.6 \pm 0.2$ & $9.0 \pm 0.6$ \\
\hline 1998 & $35.5 \pm 7.4$ & $7.9 \pm 0.8$ & $87.2 \pm 31.1$ & $4.2 \pm 0.8$ & $19.2 \pm 6.8$ & $2.1 \pm 0.3$ & $9.0 \pm 0.5$ & $9.3 \pm 1.2$ \\
\hline 1999 & $73.2 \pm 19.1$ & $7.1 \pm 1.4$ & $114.9 \pm 17.0$ & $5.8 \pm 1.3$ & $31.0 \pm 8.1$ & $1.6 \pm 0.1$ & $7.7 \pm 0.3$ & $10.3 \pm 1.3$ \\
\hline 2000 & - & $10.0 \pm 0.3$ & - & $8.9 \pm 0.8$ & - & $2.3 \pm 0.3$ & - & $9.2 \pm 0.3$ \\
\hline 1999 & $50.0 \pm 14.2$ & - & $45.5 \pm 16.4$ & - & - & - & - & - \\
\hline \multicolumn{9}{|l|}{ H-22 } \\
\hline 1997 & - & - & - & - & - & - & - & - \\
\hline 1998 & $63.1 \pm 22.6$ & $20.4 \pm 1.9$ & $30.8 \pm 3.4$ & $12.0 \pm 0.8$ & $16.3 \pm 6.4$ & $3.3 \pm 0.4$ & $12.8 \pm 1.4$ & $10.2 \pm 1.0$ \\
\hline 1999 & - & - & - & - & - & - & - & - \\
\hline
\end{tabular}

Note: Trap material was collected at $30 \mathrm{~m}$ water depth.

Table 6. Mean ( \pm standard error) lipid content (percent dry weight) of Diporeia exposed to various experimental treatments for a period of 66 days.

\begin{tabular}{lccccc}
\hline & \multicolumn{5}{l}{ Experimental treatment } \\
\cline { 3 - 6 } Day & In situ & Lake water & Sand & Sediment & \\
\cline { 3 - 6 } H-31 & M-45 \\
\hline 10 (12 May) & $31.8 \pm 1.8$ & $31.8 \pm 4.6$ & $32.6 \pm 3.2$ & $33.1 \pm 4.1$ & $29.9 \pm 2.6$ \\
19 (30 May) & - & $24.4 \pm 3.6$ & $23.4 \pm 1.8$ & $36.4 \pm 2.3$ & $28.1 \pm 2.4$ \\
27 (7 June) & - & $26.1 \pm 1.2$ & $23.9 \pm 4.9$ & $27.4 \pm 1.3$ & $24.3 \pm 3.1$ \\
41 (21 June) & - & $28.1 \pm 4.0$ & $25.8 \pm 2.4$ & $27.4 \pm 3.7$ & $26.5 \pm 2.5$ \\
66 (16 July) & $27.1 \pm 1.8$ & $22.5 \pm 7.0$ & $25.2 \pm 2.6$ & $21.3 \pm 2.2$ & $22.7 \pm 1.5$ \\
\hline
\end{tabular}

Note: In situ values were from animals collected at M-45 on the indicated dates.

starved in the laboratory (Gauvin et al. 1989). In these experiments, lipid content declined from $30 \%$ to $12 \%$ after 120 days and then increased to $18 \%$ after 191 days. The increase was attributed to the selective catabolism of non-lipid material (tissue components) after storage lipids were utilized. Weight-specific lipid content may thus increase even though absolute lipid content and total weight may decrease. This possibility seems to be refuted by the consistency in non-lipid weight (relative to length) at the $45 \mathrm{~m}$ sites over the time period when lipids increased. Further, absolute lipid content remained stable or actually increased during this period (Fig. 11). Under some circumstances, an increase in lipid content may reflect an interference with lipid degradation or lipid transport processes (Giesy et al. 1988). Accumulated lipids would thus remain unutilized as an energy source during periods of low food availability. The decline in lipid content and lack of mortality during the 66-day food-deprivation experiments indicated, however, that the animals were still able to utilize lipid material as an energy source. The increase and relatively high lipid content at the $45 \mathrm{~m}$ sites as populations disappeared suggests that biochemical-physiological changes were occurring in the animals, but the cause and meaning of such changes remain unresolved.

When Diporeia were declining, adult fecundity (eggs per brood) was similar to that found in the 1980s when abundances were high. Except in 1994, these young developed and were recruited into the population. Population declines after 1994 occurred because the YOY were not surviving to become juveniles; that is, annual peaks in YOY were generally not followed by increased numbers of juveniles. Eventually, declines in adults resulted from reduced numbers of juveniles rather than adult-specific mortality. Because of higher metabolic and growth rates, YOY are more sensitive 
Fig. 11. Mean ( \pm standard error) lipid content $(\mathrm{mg})$ of juvenile (○ - - $\bigcirc$ ) and adult ( - Diporeia spp. at (a) M-45 and

(b) H-31 over the period of declining densities at both sites.

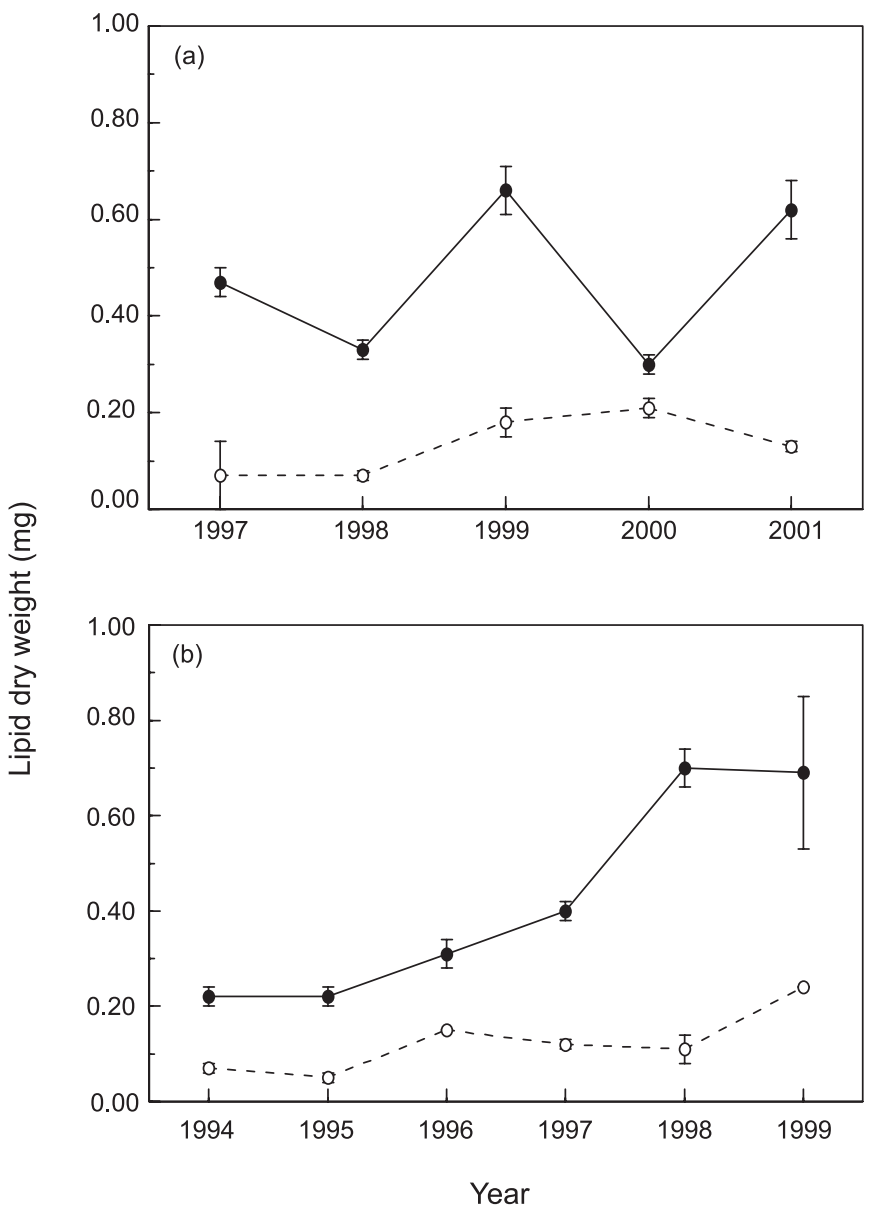

to declines in food levels than adults. In laboratory experiments assessing food competition between YOY and adults, YOY mortality was high at low to medium food regimes, whereas adults were not affected (Hill 1992; Wenngren and Olafsson 2002). Annual fluctuations in Monoporeia densities have been attributed to high mortality of YOY because of intraspecific competition for food with adults (Johnson and Wiederholm 1989; Sarvala 1986). Initial declines of juveniles relative to adults at the $45 \mathrm{~m}$ sites suggest that food limitation may indeed be a cause of the population decline, at least at these sites. Inconsistent with this premise is that lipid content of juveniles remained high and displayed spring peaks even as numbers decreased.

Nutrient content of the sediments (TOC, BiS, Chl) increased during the study period. Most likely, these increases were a result of dreissenid filtering activities rather than a result of reduced utilization by declining Diporeia populations. BiS associated with diatom frustules remains unchanged when consumed by pelagic or benthic grazers, and thus any sediment increase must reflect increased accumulation from the water column. Dreissenids effectively filter fine particulate material from the water column that otherwise would not easily settle; unassimilated material is then deposited in the form of mussel feces and pseudofeces. A 4- to 8-fold increase in sediment concentration of TOC in nearshore Lake
Erie after dreissenid colonization was attributed to the accumulation of mussel biodeposits (Howell et al. 1996).

If food limitation was the cause of declines in Diporeia, then dreissenid biodeposits must not be available as a nutrition source. Either biodeposits are too refractive to sustain Diporeia, or biodeposits are somehow having a negative impact. In laboratory microcosms, Diporeia survival was reduced by $25 \%$ when exposed to mussel pseudofeces for 90 days (Dermott et al. 2005), so perhaps there is a direct negative response. In contrast, oligochaete densities remained stable between 1993 and 1999, which may reflect an ability to utilize this material as a food source. Whether oligochaetes will persist at these densities remains unclear. In Lake Ontario, where the dreissenid expansion occurred earlier than in Lake Michigan, oligochaete densities have recently declined (Lozano et al. 2001).

Although the loss of Diporeia in the Great Lakes has been extensive since Dreissena became established, these two taxa do seem to coexist in some areas. In the Finger Lakes, New York, Diporeia abundances have not decreased despite an increase in dreissenids over the same time period (Dermott et al. 2005). In Lake Michigan, Diporeia continue to be present (although in reduced numbers) at a site $<30 \mathrm{~m}$ on the western side of the southern basin despite the presence of dreissenids. Upwellings are more frequent on the west side (Plattner et al. 2006), which create conditions of lower temperature and higher productivity that are favorable to Diporeia. Lower temperatures associated with upwelling cannot entirely explain the continued presence of Diporeia at this shallow, west-side site - populations on the east side disappeared at depths below the thermocline $(>30 \mathrm{~m})$ where temperatures were as consistently cold as shallow areas on the west side subject to upwellings. The persistence of $D i$ poreia at this site may be temporary, but it does further illustrate the inconsistency associated with temporal and spatial patterns of decline.

Similar to declines of Diporeia in the Great Lakes, the related deepwater amphipod Monoporeia is also declining in the Baltic Sea (Perus and Bonsdorff 2004). Interestingly, circumstances associated with Monoporeia's decline, as well as uncertainties of potential causes, closely parallel those for Diporeia. The decline of Monoporeia in most areas was temporally coincident with the invasion of the Baltic by the polycheate Marenzellaria viridis (Perus and Bonsdorff 2004). This polychaete is a detritivore and believed to be competing directly with Monoporeia for available food resources. Yet the decline in Monoporeia was greater in offshore areas $(>30 \mathrm{~m})$ than in nearshore areas, even though densities of Marenzellaria were greater in the latter (Cederwall et al. 1999). Low oxygen levels have been suggested as the reason for the decline in offshore waters, but others suggest it is food limitation (Cederwall et al. 1999; Kotta and Olafsson 2003). Also, in some parts of the Baltic, the collapse of Monoporeia occurred prior to the establishment of Marenzellaria (B. Sundelin, Department of Applied Environmental Science, Stockholm University, SE-106 91 Stockholm, Sweden, personal communication).

The decline of Diporeia in Lake Michigan, first observed in 1992, continued through 2002. This decline represents a major loss of energy to upper trophic levels. For example, most fish in Lake Michigan are found at depths $<90 \mathrm{~m}$ 
(Wells 1968). In 1994-1995, mean dry weight biomass (B) of Diporeia at depths $<90 \mathrm{~m}$ was $4.8 \mathrm{~g} \cdot \mathrm{m}^{-2}$ (Nalepa et al. 2000). Lakewide production $(P)$ at $<90 \mathrm{~m}$ was thus calculated as $7.7 \mathrm{~g} \cdot \mathrm{m}^{-2}$ (assuming $P=B \times T^{2} / 10$ (Johnson and Brinkhurst 1971) and a mean temperature $(T)$ of $4{ }^{\circ} \mathrm{C}$ ). Further assuming that differences in size frequencies and lengths-weights of the Diporeia population were minimal between 1994-1995 and 2000, the amount of secondary production lost to fish over this period was $5.1 \mathrm{~g} \cdot \mathrm{m}^{-2}$. While this represents a substantial loss, the decline of Diporeia has other implications to the fish community besides the loss of a major producer of secondary biomass. Diporeia have a higher lipid content and therefore more calories than most other invertebrate prey items. So even if fish switch to other prey, fish bioenergetics will still likely be affected. As evidence, condition and growth of lake whitefish have declined since the loss of Diporeia even though alternate prey have been found in their stomachs (Pothoven et al. 2001; Hoyle et al. 2003). A decrease in energy density and (or) lipid content of fish species that serve as prey for the larger piscivores, such as alewife and sculpin, have been attributed to the decline of Diporeia (Madenjian et al. 2003; Hondorp et al. 2005). The recent introduction and expansion of quagga mussels into deeper regions of Lake Michigan will likely lead to further declines in Diporeia and, hence, further impacts on fish populations.

In summary, features of declining Diporeia populations in Lake Michigan were highly variable. Depending on the site, declines in abundances were rapid and apparent in all age classes, or declines were more extended and mostly a result of poor juvenile survival. The former suggests mass mortality in response to perhaps a dreissenid toxic agent, whereas the latter suggests possible food limitation from dreissenid filtering activities. Our quantitative and limited qualitative measures of benthic food inputs, along with observed changes in physiological well-being and laboratory mortalityavoidance experiments, failed to provide conclusive evidence of a cause. Inconsistencies apparent in our results may imply a multitude of causative factors whose relative importance may vary depending on specific environmental conditions. If food limitation is the sole cause, then a nutritional problem not evident from our measures of gross food inputs or physiological well-being is a possibility. Given this, detailed studies of cellular or biochemical indicators may prove worthwhile. For instance, profiles of essential fatty acids (Brett and Muller-Navarra 1997) or functional protein groups (Lopez et al. 2001) in areas with declining and stable populations may show differences specific to nutritional deficiencies or to disease-defense mechanisms. Populations from areas subject to upwelling-downwelling and high-low sedimentation would be of particular interest. By better understanding reasons for Diporeia's decline relative to increased numbers of dreissenids, we may better predict the eventual extent and ultimate consequences of the population loss.

\section{Acknowledgements}

We thank the crews of the R/Vs Shenehon, Laurentian, and Lake Guardian for their support during field operations; the Great Lakes National Program Office, US Environmental Protection Agency for use of the Lake Guardian; and
Jennifer Buchannan, Glenn Carter, Joann Cavaletto, Gerry Gostenik, David Hartson, Margaret Lansing, Nancy Morehead, Rosalie de Rosario, and Ann Vielmetti for assistance over the many years of this study. We also thank Charles Madenjian for statistical advice. This is Great Lakes Environmental Research Laboratory Publication No. 1366.

\section{References}

Anderson, E.D., and Smith, L.L., Jr. 1971. A synoptic study of food habits of 30 fish species from western Lake Superior. Univ. Minn. Agri. Exp. Stn. Tech. Bull. 279.

Bousfield, E.L. 1989. Revised morphological relationships within the amphipod genera Pontoporeia and Gammaracanthus and the "glacial relict" significance of their postglacial distributions. Can. J. Fish. Aquat. Sci. 46: 1714-1725.

Brett, M.T., and Mueller-Navarra, D.C. 1997. The role of highly unsaturated fatty acids in aquatic foodweb processes. Freshw. Biol. 38: 483-499.

Cavaletto, J.F., Nalepa, T.F., Dermott, R., Gardner, W.S., Quigley, M.A., and Lang, G.A. 1996. Seasonal variation of lipid composition, weight, and length in juvenile Diporeia spp. (Amphipoda) from Lakes Michigan and Ontario. Can. J. Fish. Aquat. Sci. 53: 2044-2051.

Cederwall, H., Jermakovs, V., and Lagzdins, G. 1999. Long-term changes in the soft-bottom macrofauna of the Gulf of Riga. ICES J. Mar. Sci. 56(Suppl.): 41-48.

Cook, D.G., and Johnson, M.G. 1974. Benthic macroinvertebrates of the St. Lawrence Great Lakes. J. Fish. Res. Board Can. 31: $763-782$.

Dermott, R. 2001. Sudden disappearance of the amphipod Diporeia from eastern Lake Ontario, 1993-1995. J. Gt. Lakes Res. 27: $423-433$.

Dermott, R., and Corning, K. 1988. Seasonal ingestion rates of Pontoporeia hoyi (Amphipoda) in Lake Ontario. Can. J. Fish. Aquat. Sci. 45: 1886-1895.

Dermott, R., and Kerec, D. 1997. Changes to the deepwater benthos of eastern Lake Erie since the invasion of Dreissena: 1979-1993. Can. J. Fish. Aquat. Sci. 54: 922-930.

Dermott, R., Munawar, M., Bonnell, R., Carou, S., Niblock, H., Nalepa, T.F., and Messick, G.A. 2005. Preliminary investigations for causes of the disappearance of Diporeia spp. from Lake Ontario. In Proceedings of a Workshop on the Dynamics of Lake Whitefish (Coregonus clupeaformis) and the Amphipod Diporeia spp. in the Great Lakes, Ann Arbor, Michigan, 27 February 2002. Edited by L.C. Mohr and T.F. Nalepa. Great Lakes Fish. Comm. Tech. Rep. 66. pp. 203-232.

Dorgelo, J., and Leonards, P.E.G. 2001. Relationship between C/N ratio of food types and growth rate in the snail Potamopyrgus jenkinsi (E.A. Smith). J. N. Am. Benthol. Soc. 20: 60-67.

Eadie, B.J., Schwab, D.J., Johengen, T.H., Lavrentyev, P.J., Miller, G.S., Holland, R.E., Leshkevich, G.A., Lansing, M.B., Morehead, N.R., Robbins, J.A., Hawley, N., Edgington, D.N., and Van Hoof, P.L. 2002. Particle transport, nutrient cycling, and algal community structure associated with a major winter-spring sediment resuspension event in southern Lake Michigan. J. Gt. Lakes Res. 28: $324-337$.

Fitzgerald, S.A., and Gardner, W.S. 1993. An algal carbon budget for pelagic-benthic coupling in Lake Michigan. Limnol. Oceanogr. 38: 547-560.

Gardner, W.S., Frez, W.A., Cichocki, E.A., and Parrish, C.C. 1985a. Micromethod for lipids in aquatic invertebrates. Limnol. Oceanogr. 30: 1099-1105. 
Gardner, W.S., Nalepa, T.F., Frez, W.A., Cichocki, E.A., and Landrum, P.F. 1985b. Seasonal patterns in lipid content of Lake Michigan macroinvertebrates. Can. J. Fish. Aquat. Sci. 42: $1827-1832$.

Gardner, W.S., Eadie, B.J., Chandler, J.F., Parrish, C.C., and Malczyk, J.M. 1989. Mass flux and "nutritional composition" of settling epilimnetic particles in Lake Michigan. Can. J. Fish. Aquat. Sci. 46: 1118-1124.

Gardner, W.S., Quigley, M.A., Fahnenstiel, G.L., Scavia, D., and Frez, W.A. 1990. Pontoporeia hoyi - a direct trophic link between spring diatoms and fish in Lake Michigan. In Large lakes: structure and functional properties. Edited by M.M. Tilzer and C. Serruya. Springer, New York. pp. 632-644.

Gauvin, J.M., Gardner, W.S., and Quigley, M.A. 1989. Effects of food removal on nutrient release rates and lipid content of Lake Michigan Pontoporeia hoyi. Can. J. Fish. Aquat. Sci. 46: 1125-1130.

Giesy, J.P., Versteeg, D.J., and Graney, R.L. 1988. A review of selected clinical indicators of stress-induced changes in aquatic organisms. In Toxic contaminants and ecosystem health: a Great Lakes focus. Edited by M.S. Evans. John Wiley \& Sons, New York. pp. 169-200.

Goedkoop, W., and Johnson, R.K. 2001. Factors affecting population fluctuations of the glacial amphipod Monoporeia affinis (Lindstrom) in Sweden's largest lakes. Ambio, 30: 552-558.

Hansson, L.-A. 1988. Chlorophyll $a$ determination of periphyton on sediments: identification of problems and recommendation of method. Freshw. Biol. 20: 347-352.

Hecky, R.E., Smith, R.E.H., Barton, D.R., Guildford, S.J., Taylor, W.D., Charlton, M.N., and Howell, T. 2004. The nearshore phosphorus shunt: a consequence of ecosystem engineering by dreissenids in the Laurentian Great Lakes. Can. J. Fish. Aquat. Sci. 61: 1285-1293.

Hill, C. 1992. Interactions between year classes in the benthic amphipod Monoporeia affinis: effects on juvenile survival and growth. Oecologia, 91: 157-162.

Hill, C., Quigley, M.A., Cavaletto, J.F., and Gordon, W. 1992. Seasonal changes in lipid content and composition in the benthic amphipods Monoporeia affinis and Pontoporeia femorata. Limnol. Oceanogr. 37: 1280-1289.

Hondorp, D.W., Pothoven, S.A., and Brandt, S.B. 2005. Influence of Diporeia density on the diet composition, relative abundance, and energy density of planktivorous fishes in southeast Lake Michigan. Trans. Am. Fish. Soc. 134: 588-601.

Howell, E.T., Marvin, C.H., Bilyea, R.W., Kauss, P.B., and Somers, K. 1996. Changes in environmental conditions during Dreissena colonization of a monitoring station in eastern Lake Erie. J. Gt. Lakes Res. 22: 744-756.

Hoyle, J.A., Casselman, J.M., Dermott, R., and Schaner, T. 2003. Resurgence and decline of lake whitefish (Coregonus clupeaformis) stocks in eastern Lake Ontario, 1972-1999. In State of Lake Ontario - past, present, and future. Edited by M. Munawar. Ecovision World Monograph Series, Goodword Books Ltd., New Delhi, India.

Johnson, M.G. 1988. Production by the amphipod Pontoporeia hoyi in South Bay, Lake Huron. Can. J. Fish. Aquat. Sci. 45: 617-624.

Johnson, M.G., and Brinkhurst, R.O. 1971. Production of benthic macroinvertebrates of Bay of Quinte and Lake Ontario. J. Fish. Res. Board Can. 28: 1699-1714.

Johnson, R.K., and Wiederholm, T. 1989. Long-term growth oscillations of Pontoporeia affinis Lindstrom (Crustacea: Amphipoda) in Lake Malaren. Hydrobiologia, 175: 183-194.

Johnson, R.K., and Wiederholm, T. 1992. Pelagic-benthic coupling — the importance of diatom interannual variability for population oscillations of Monoporeia affinis. Limnol. Oceanogr. 37: 1596-1607.

Kotta, J., and Olafsson, E. 2003. Competition for food between the introduced polychaete Marenzelleria viridis (Verrill) and the native amphipod Monoporeia affinis Lindstrom in the Baltic Sea. J. Sea Res. 50: 27-35.

Krausse, G.L., Shelske, C.L., and Davis, C.O. 1983. Comparison of three wet-alkaline methods of digestion of biogenic silica in water. Freshw. Biol. 13: 73-81.

Landrum, P.F., Gossiaux, D.C., Nalepa, T.F., and Fanslow, D.L. 2000. Evaluation of Lake Michigan sediment for causes of the disappearance of Diporeia spp. in southern Lake Michigan. J. Gt. Lakes Res. 26: 402-407.

Lehtonen, K.K. 1996. Ecophysiology of the benthic amphipod Monoporeia affinis in an open-sea area of the northern Baltic Sea: seasonal variations in body composition, with bioenergetic considerations. Mar. Ecol. Progr. Ser. 143: 87-98.

Lopez, J.L., Marina, A., Vazquez, J., and Alvarez, G. 2001. A proteomic approach to the study of the marine mussels Mytilus edulis and M. galloprovincailis. Mar. Biol. 141: 217-223.

Lozano, S.J., Scharold, J.V., and Nalepa, T.F. 2001. Recent declines in benthic macroinvertebrate densities in Lake Ontario. Can. J. Fish. Aquat. Sci. 58: 518-529.

Madenjian, C.P., Holuszko, J.D., and DeSorcie, T.J. 2003. Growth and condition of alewives in Lake Michigan, 1984-2001. Trans. Am. Fish. Soc. 132: 1104-1116.

Marsden, J.E., Trudeau, N., and Keniry, T. 1993. Zebra mussel study of Lake Michigan. Aquat. Ecol. Tech. Rep. 93/14. Illinois Natural History Survey, Zion, Ill.

Muzzi, R.W., and Eadie, B.J. 2002. The design and performance of sequencing sediment trap for lake research. Mar. Tech. Soc. J. 36: $23-28$.

Nalepa, T.F. 1987. Long-term changes in the macrobenthos of southern Lake Michigan. Can. J. Fish. Aquat. Sci. 44: 515-524.

Nalepa, T.F. 1989. Estimates of macroinvertebrate biomass in Lake Michigan. J. Gt. Lakes Res. 15: 437-443.

Nalepa, T.F., Hartson, D.J., Gostenik, G.W., Fanslow, D.L., and Lang, G.A. 1996. Changes in the freshwater mussel community of Lake St. Clair: from Unionidae to Dreissena polymorpha in eight years. J. Gt. Lakes Res. 22: 354-369.

Nalepa, T.F., Hartson, D.J., Fanslow, D.L., Lang, G.A., and Lozano, S.J. 1998. Declines in benthic macroinvertebrate populations in southern Lake Michigan, 1980-1993. Can. J. Fish. Aquat. Sci. 55: 2402-2413.

Nalepa, T.F., Hartson, D.J., Buchanan, J., Cavaletto, J.F., Lang, G.A., and Lozano, S.J. 2000. Spatial variation in density, mean size and physiological condition of the holarctic amphipod Diporeia spp. in Lake Michigan. Freshw. Biol. 43: 107-119.

Nalepa, T.F., Fanslow, D.L., Lansing, M.B., and Lang, G.A. 2003. Trends in the benthic macroinvertebrate community of Saginaw Bay, Lake Huron, 1987 to 1996: responses to phosphorus abatement and the zebra mussel, Dreissena polymorpha. J. Gt. Lakes Res. 29: 14-33.

Perus, J., and Bonsdorff, E. 2004. Long-term changes in macrobenthos in the Aland archipelago, northern Baltic Sea. J. Sea Res. 52: 45-56.

Plattner, S., Mason, D.M., Leshkevich, G.A., Schwab, D.J., and Rutherford, E.S. 2006. Classifying and predicting coastal upwellings in Lake Michigan using satellite derived temperature images and buoy data. J. Gt. Lakes Res. 32. In press.

Pothoven, S.A., Nalepa, T.F., Schneeberger, P.J., and Brandt, S.B. 2001. Changes in diet and body condition of lake whitefish in southern Lake Michigan associated with changes in benthos. N. Am. J. Fish. Manag. 21: 876-883. 
Quigley, M.A., and Lang, M.A. 1989. Measurement of amphipod body length using a digitizer. Hydrobiologia, 223: 255-258.

Sarvala, J. 1986. Interannual variation of growth and recruitment in Pontoporeia affinis (Lindstrom) (Crustacea: Amphipoda) in relation to abundance fluctuations. J. Exp. Mar. Biol. Ecol. 101: 41-59.

Scavia, D., and Fahnenstiel, G.L. 1987. Dynamics of Lake Michigan phytoplankton: mechanisms controlling epilimnetic communities. J. Gt. Lakes Res. 13: 103-120.

Scott, W.B., and Crossman, E.J. 1973. Freshwater fishes of Canada. Bull. Fish. Res. Board Can. No. 184.

Simon, K.S., and Townsend, C.R. 2003. Impacts of freshwater invaders at different levels of ecological organisation, with emphasis on salmonids and ecosystem consequences. Freshw. Biol. 48: 982-994.

Soderstrom, O. 1988. Effects of temperature and food quality on life-history parameters in Parameletus chelifer and P. minor (Ephemeroptera): a laboratory study. Freshw. Biol. 20: 295-303.

Strayer, D.L., and Smith, L.C. 2001. The zoobenthos of the freshwater tidal Hudson River and its response to the zebra mussel (Dreissena polymorpha) invasion. Arch. Hydrobiol. 139: 1-52.
Vanderploeg, H.A., Nalepa, T.F., Jude, D.J., Mills, E.L., Holeck, K.T., Liebig, J.R., Grigorovich, I.A., and Ojaveer, H. 2002. Dispersal and emerging ecological impacts of Ponto-Caspian species in the Laurentian Great Lakes. Can. J. Fish. Aquat. Sci. 59: 1209-1228.

Wells, L. 1968. Seasonal depth distribution of fish in southeastern Lake Michigan. U.S. Fish. Wild. Serv. Fish. Bull. 67: 1-15.

Wells, L. 1980. Food of alewives, yellow perch, spottail shiners, trout-perch, and slimy and fourhorn sculpins in southeastern Lake Michigan. U.S. Fish Wild. Serv. Tech. Rep. 98.

Wenngren, J., and Olafsson, E. 2002. Intraspecific competition for food within and between year classes in the deposit-feeding amphipod Monoporeia affinis - the cause of population fluctuations? Mar. Ecol. Prog. Ser. 240: 205-213.

Wetzel, R.G. 2001. Limnology: lake and river systems. 3rd ed. Academic Press, San Diego, Calif.

Winnell, M.H., and White, D.S. 1984. Ecology of shallow and deep water populations of Pontoporeia hoyi (Smith) (Amphipoda) in Lake Michigan. Freshw. Invertebr. Biol. 3: 118-136. 